$\approx$ GP

science for a changing world

METHODS OF ANALYSIS BY THE U.S. GEOLOGICAL SURVEY NATIONAL WATER QUALITY LABORATORY-DETERMINATION OF TOTAL PHOSPHORUS BY A KJELDAHL DIGESTION METHOD AND AN AUTOMATED COLORIMETRIC FINISH THAT INCLUDES DIALYSIS

USS. GEOLOGICAL SURVEY

Open-File Report 92-146 


\section{METHODS OF ANALYSIS BY THE U.S. GEOLOGICAL SURVEY NATIONAL WATER QUALITY LABORATORY-DETERMINATION OF TOTAL PHOSPHORUS BY A KJELDAHL DIGESTION METHOD AND AN AUTOMATED COLORIMETRIC FINISH THAT INCLUDES DIALYSIS}

By Charles J. Patton and Earl P. Truitt

U.S. GEOLOGICAL SURVEY

Open-File Report 92-146 


\section{U.S. DEPARTMENT OF THE INTERIOR \\ MANUEL LUJAN, JR., Secretary \\ U. S. GEOLOGICAL SURVEY \\ Dallas L. Peck, Director}

For additional information write to:

U.S. Geological Survey Chief, National Water Quality Laboratory

Box 25046, Mail Stop 407

Federal Center

Denver, CO 80225-0046
Copies of this report can be purchased from:

U.S. Geological Survey Branch of Information Services Box 25286

Federal Center

Denver, CO 80225-0286 


\section{ERRATA SHEET}

Page 8, paragraph 6.2.8 - added.

6.2.8 Diluent. Use a digital microliter ( $\mu \mathrm{L}$ ) pipet to add $100 \mu \mathrm{L}$ of Brij-35 (30 percent $\mathrm{w} / \mathrm{v}$ ) surfactant to $100 \mathrm{~mL}$ of deionized water.

NOTE: Brij-35 surfactant is used in the alkaline donor stream, because sodium lauryl sulfate (SLS) surfactant precipitates.

Page 39, references - added.

Fishman, M.J., and Friedman, L.C., 1989, Methods for determination of inorganic substances in water and fluvial sediments: U.S. Geological Survey Techniques of Water-Resources Investigations, book 5, chap. A1, 545 p.

U.S. Geological Survey, 1992, Programs and plans-Phosphorus methods and the quality of phosphorus data: Office of Water Quality Technical Memorandum No. 92.10, accessed April 28, 2003, at URL http://water.usgs.gov/admin/memo/QW/qw92.10.html 


\section{CONTENTS}

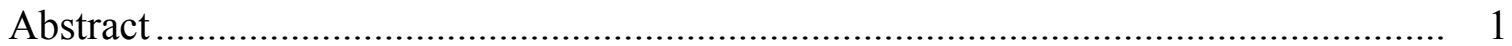

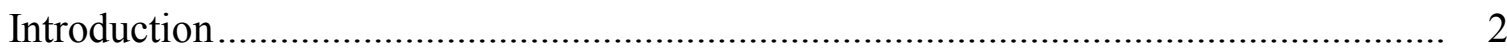

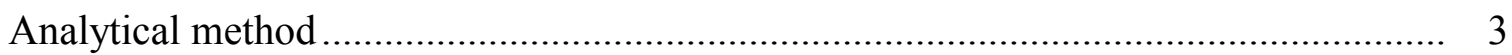

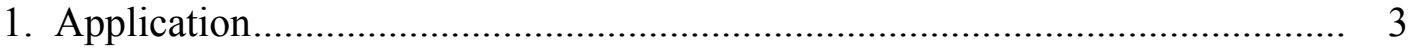

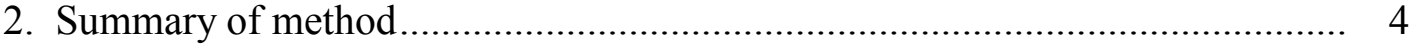

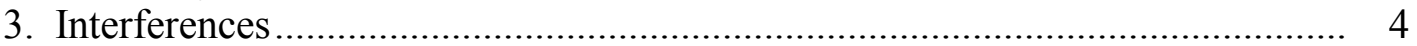

4. Instrumentation ............................................................................... 5

5. Apparatus .......................................................................................... 5

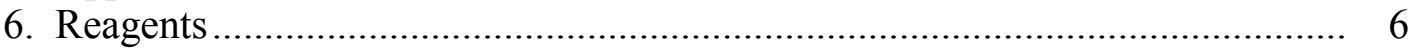

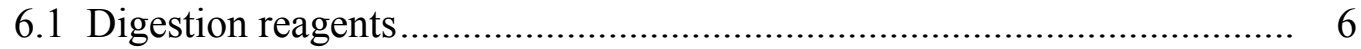

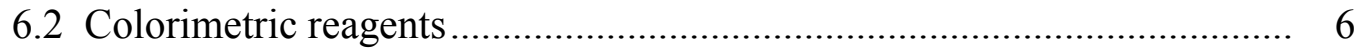

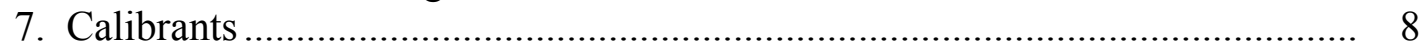

7.1 Primary calibrant, phosphorus, inorganic ........................................... 8

7.2 Primary calibrant, phosphorus, organic ........................................... 8

7.3 Working calibrants.......................................................................... 8

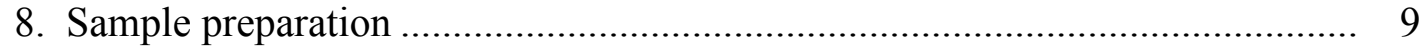

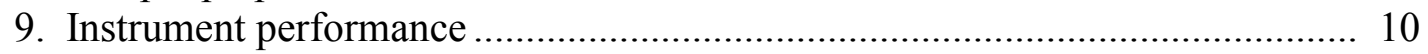

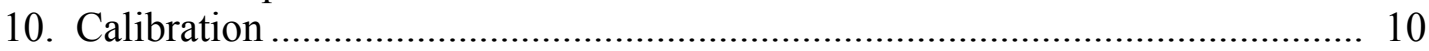

11. Procedure and data evaluation ................................................................ 11

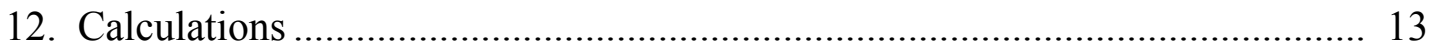

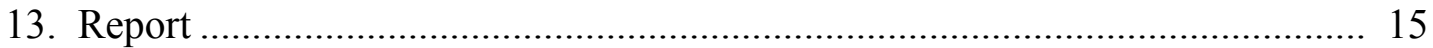

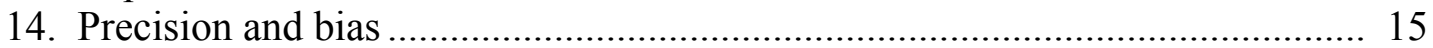

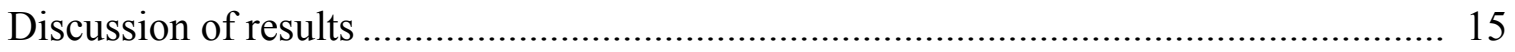

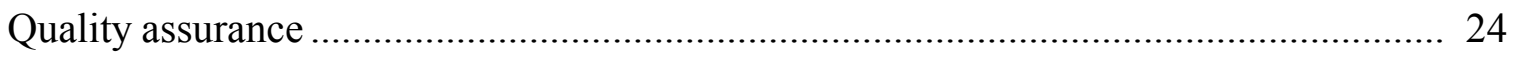

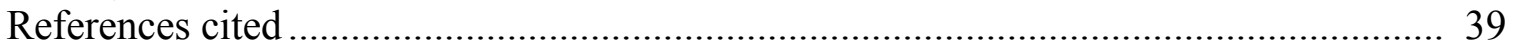

\section{FIGURES}

1. Typical calibration plot for determination of orthophosphate in digests prepared by methods I-2610/4610-91......

2. Analytical cartridge diagram for determination of total phosphorus concentration by methods I-2610/4610-91

3-13. Graphs showing:

3. Total phosphorus blank concentrations determined by methods I-2610/4610-91 during the April 1991 experiment

4. Total phosphorus blank concentrations determined by methods I-2600/4600-85 during the April 1991 experiment.

5. Relation between total phosphorus concentrations determined in filtered surface-water samples by methods I-2600/4600-85 and total phosphorus concentrations determined by methods I-2610/4610-91 
6. Relation between total phosphorus concentrations determined in unfiltered surface-water samples by methods I-2600/4600-85 and total phosphorus concentrations determined by methods I-2610/4610-91

7. Relation between total phosphorus concentrations determined in filtered and unfiltered ground-water samples by methods I-2600/4600-85 and total phosphorus concentrations determined by methods I-2610/4610-91

8. Relation between total phosphorus concentrations determined in filtered and unfiltered resolvated Heidelberg sample digests by methods I-2610/4610-91

9. Total phosphorus concentration recovered for a sample in a high suspendedsolids matrix and adenosin 5 ' triphosphate in deionized water by methods I-2610/4610-91 as a function of high-temperature digestion time.

10. Repeatability (within-run precision) for 55 replicate determinations of the Heidelberg sample for total phosphorus concentration using methods I-2610/4610-91

11. Duplicate replication for total phosphorus concentration determined by methods I-2610/4610-91....

12. Duplicate replication during the April 1991 experiment for total phosphorus concentration determined by methods I-2610/4610-91

13. Spike recovery during the April 1991 experiment for total phosphorus concentration determined by methods I-2610/4610-91

\section{TABLES}

1. Calibrant preparation protocol

2. Suggested block protocol for determination of total phosphorus by methods I-2610/4610-91

3. Suggested tray protocol for automated determination of

orthophosphate in resolvated digests by methods I-2610/4610-91

4. Data used to estimate the method detection limit for total phosphorus determination by methods I-2610/4610-91

5. Paired $t$-test analysis of total phosphorus concentrations in filtered surfacewater samples determined by methods I-2600/4600-85 (variable 1) and methods I-2610/4610-91 (variable 2) for the April 1991 experiment.

6. Paired $t$-test analysis of total phosphorus concentrations in filtered surfacewater samples determined by methodsI-2600/4600-85 (variable 1) and methods I-2610/4610-91 (variable 2) for the July through September 1991 experiments

7. Paired $t$-test analysis of total phosphorus concentrations in unfiltered surfacewater samples determined by methods I-2600/4600-85 (variable 1) and methods I-2610/4610-91 (variable 2) for the April 1991 experiment.....

8. Paired $t$-test analysis of total phosphorus concentrations in unfiltered surfacewater samples determined by methods I-2600/4600-85 (variable 1) and methods I-2610/4610-91 (variable 2) for the July through September 1991 experiments 
9. Paired $t$-test analysis of total phosphorus concentrations in filtered and unfiltered ground-water samples determined by methods I-2600/4600-85 (variable 1) and methods I-2610/4610-91 (variable 2) for the April 1991 experiment.

10. Paired $t$-test analysis of total phosphorus concentrations in filtered and unfiltered ground-water samples determined by methods I-2600/4600-85 (variable 1) and methods I-2610/4610-91 (variable 2) for the July through September 1991 experiments

11. Total phosphorus concentrations determined by methods I-2610/4610-91 for resolvated Heidelberg sample digests before and after passage through a 0.45 micrometer nylon syringe filter.

12. Repeatability (within-run precision, May 3, 1991) data for 55 replicate determinations of total phosphorus concentration in the Heidelberg sample using methods I-2610/4610-91

13. Between-day (April 8-26, 1991) precision of digested calibrants and the Heidelberg sample for total phosphorus determination using methods I-2610/4610-91

14. Between-day (April 8-26, 1991) accuracy of digested U.S. Environmental Protection Agency and U.S. Geological Survey reference samples for total phosphorus determination using methods I-2610/4610/91 


\section{CONVERSION FACTORS, ABBREVIATED WATER-QUALITY UNITS, AND ADDITIONAL ABBREVIATIONS AND SYMBOLS}

\begin{tabular}{lcl}
\multicolumn{1}{c}{ Multiply } & By & To obtain \\
centimeter $(\mathrm{cm})$ & $3.94 \times 10^{-1}$ & inch \\
gram $(\mathrm{g})$ & $3.53 \times 10^{-2}$ & ounce \\
millimeter $(\mathrm{m})$ & 25.4 & inch \\
liter $(\mathrm{L})$ & 0.265 & gallon \\
meter $(\mathrm{m})$ & 3.28 & foot \\
microgram $(\mu \mathrm{g})$ & $3.53 \times 10^{-8}$ & ounce \\
microliter $(\mu \mathrm{L})$ & $2.64 \times 10^{-7}$ & gallon \\
micrometer $(\mu \mathrm{m})$ & $3.94 \times 10^{-5}$ & inch \\
milligram $(\mathrm{mg})$ & $3.53 \times 10^{-5}$ & ounce \\
milliliter $(\mathrm{mL})$ & $2.64 \times 10^{-4}$ & gallon \\
milliliter per minute $(\mathrm{mL} / \mathrm{min})$ & $3.38 \times 10^{-2}$ & ounce per minute \\
millimeter $(\mathrm{mm})$ & $3.94 \times 10^{-2}$ & inch
\end{tabular}

Degree Celsius $\left({ }^{\circ} \mathrm{C}\right)$ may be converted to degree Fahrenheit $\left({ }^{\circ} \mathrm{F}\right)$ by using the following equation:

$$
\mathrm{oF}=9 / 5\left({ }^{\circ} \mathrm{C}\right)+32 .
$$

Water-quality terms and abbreviations used in this report are as follows:

microgram per liter $(\mu \mathrm{g} / \mathrm{L})$

milligram per liter $(\mathrm{mg} / \mathrm{L})$

Other abbreviations and symbols used in this report are as follows:

\begin{tabular}{|c|c|c|c|}
\hline $\mathrm{A} / \mathrm{D}$ & analog-to-digital & $\mathrm{P}$ & phosphorus \\
\hline ATP & adenosin $5^{\prime}$ triphosphate & $p$ & probability level \\
\hline USEPA & U.S. Environmental Protection Agency & $\mathrm{PC}$ & personal computer \\
\hline $\mathrm{FC}$ & chilled, filtered, mercury preserved & QC & quality control \\
\hline $\mathrm{F} / \mathrm{C}$ & flow cell & $\mathrm{RC}$ & chilled, unfiltered, mercury \\
\hline $\mathrm{h}$ & hour & & preserved \\
\hline $\mathrm{Hz}$ & hertz $\left(s^{-1}\right)$ & $\mathrm{sp} g \mathrm{gr}$ & specific gravity \\
\hline M & molarity $($ moles/L) & TKN & total Kjeldahl nitrogen \\
\hline MDL & method detection limit & $\mathrm{TP}$ & total phosphorus \\
\hline $\min$ & minute & $\mathrm{v} / \mathrm{v}$ & volume per volume \\
\hline$N$ & normality (equivalents/L) & $\mathrm{w} / \mathrm{w}$ & weight per weight \\
\hline $\mathrm{nm}$ & nanometer & $\mu \mathrm{m}$ & micrometer \\
\hline NWQL & National Water Quality Laboratory & $\approx$ & approximately \\
\hline
\end{tabular}




\title{
METHODS OF ANALYSIS BY THE U.S. GEOLOGICAL SURVEY NATIONAL WATER QUALITY LABORATORY-DETERMINATION OF TOTAL PHOSPHORUS BY A KJELDAHL DIGESTION METHOD AND AN AUTOMATED COLORIMETRIC FINISH THAT INCLUDES DIALYSIS
}

\author{
By CHARLES J. PATTON AND EARL P. TRUITT
}

\section{ABSTRACT}

A method to determine total phosphorus (TP) in the same digests prepared for total Kjeldahl nitrogen (TKN) determinations is described. The batch, high-temperature (block digester), $\mathrm{Hg}$ (II)-catalyzed digestion step is similar to U.S. Geological Survey methods I-2552-85/I-4552-85 and U.S. Environmental Protection Agency method 365.4 except that sample and reagent volumes are halved. Prepared digests are desolvated at 220 degrees Celsius $\left({ }^{\circ} \mathrm{C}\right)$ and digested at $370^{\circ} \mathrm{C}$ in separate block digesters set at these temperatures, rather than in a single, temperature-programmed block digester. This approach is used in the method described here, which permits 40 calibrants, reference waters, and samples to be digested and resolvated in about an hour. Orthophosphate ions originally present in samples, along with those released during the digestion step, are determined colorimetrically at a rate of 90 tests per hour by an automated version of the phosphoantimonylmolybdenum blue procedure. About 100 microliters of digest are required per determination. The upper concentration limit is 2 milligrams per liter $(\mathrm{mg} / \mathrm{L})$ with a method detection limit of 0.01 $\mathrm{mg} / \mathrm{L}$. Repeatability for a sample containing approximately $1.6 \mathrm{mg} / \mathrm{L}$ of TP in a high suspended-solids matrix is 0.7 percent. Between-day precision for the same sample is 5.0 percent. A dialyzer in the air-segmented continuous flow analyzer provides on-line digest cleanup, eliminating particulates that otherwise would interfere in the colorimetric finish. A single-channel analyzer can process the resolvated digests from two pairs of block digesters each hour. Paired $t$-test analysis of TP concentrations for approximately 1,600 samples determined by the new method (U.S. Geological Survey methods I-2610-91 and I-4610-91) and the old method (U.S. Geological Survey methods I-2600-85 and I-4600-85) revealed positive bias in the former of 0.02 to $0.04 \mathrm{mg} / \mathrm{L}$ for surface-water samples in agreement with previous studies. Concentrations of total phosphorus determined for ground-water samples by both methods were statistically equivalent. 


\section{INTRODUCTION}

In 1991, the National Water Quality Laboratory (NWQL) determined total phosphorus (TP) in about 15,000 surface- and ground-water samples. Organic phosphorus in these samples was converted into orthophosphate ions with an acidic persulfate reagent in an autoclave, similar to U.S. Environmental Protection Agency (USEPA) method 365.1 (U.S. Environmental Protection Agency, 1983, p. 365.1-1). Since the early 1970's, however, an alternate method (U.S. Environmental Protection Agency, 1983, p. 365.4-1) in which TP is determined in Kjeldahl nitrogen digests has been widely applied. Because both TP and total Kjeldahl nitrogen (TKN) are determined in a common digest, the time required for pre- and post-digestion sample-handling operations is halved. Jirka and others (1976) showed that if sample and reagent volumes were halved relative to USEPA method 365.4, the overall digestion time could be reduced from $\approx 4$ hour to $\approx 90$ minutes. Both USEPA method 365.4 and Jirka's modification of it used a single, temperature-programmed block digester. Bowman and Delfino (1982) used two block digesters, one set at the desolvation temperature $\left(\approx 200^{\circ} \mathrm{C}\right)$, the other set at the digestion temperature $\left(\approx 370^{\circ} \mathrm{C}\right)$. This method eliminated the time required to ramp a single block digester from the desolvation temperature to the digestion temperature. This approach is used in the method described here, which permits a batch of 40 calibrants, reference waters, and samples to be desolvated and digested in 45 minutes. Interference from particulates in resolvated digests is eliminated by incorporation of a dialyzer into the analyzer used for the colorimetric finish. In addition to increased production capacity, benefits afforded by this method include decreased exposure of analysts to caustic and toxic materials, lower reagent and reagent preparation costs, and lower costs associated with proper disposal of caustic and toxic wastes resulting from determination of total phosphorus.

Data in this report result from two distinct studies that were conducted in 1991. The first study, in April, was primarily an internal effort to assess the feasibility of determining TP and TKN in a common Kjeldahl digest at the NWQL. During this study much effort was expended to characterize performance of the new method and to establish quality-control (QC) guidelines for routine operation. All data that appear in this report relating to analytical figures of merit--precision and accuracy of analytical results, the method detection limit, and blank concentration values--were collected during the April study. In addition, all samples with test requests for both TKN and TP that were received at the NWQL in April 1991 were determined for TP (and TKN) by the new method. The result was a data base containing about 450 pairs of concentration values for TP that had been determined by the old method (U.S. Geological Survey methods I-2600-85/I-4600-85) and by the new method (U.S. Geological Survey methods I-2610-91/I-4610-91). This data base was used for initial assessment of bias between the two methods. 
The second study--during the months of July, August, and September 1991--was performed primarily to address U.S. Geological Survey (USGS) concerns that the full range of water types, which are commonly sent to the NWQL for nutrient determinations, was not adequately represented in the April study. During these months, $\approx 1,200$ additional samples, selected by the USGS, were determined by both methods. Results of this comparison are included here, but QC and other analytical performance-related data that closely matched those from the April study are not.

This report describes a method for determining total phosphorus developed by the USGS for use in the Survey's NWQL. The method supplements other methods of the USGS for determination of inorganic substances in water that are described by Fishman and Friedman (1989). The method was implemented in the NWQL in October 1991.

This report provides a detailed description of all aspects of the method from sample preparation through calculation and reporting of results. Precision and accuracy data are included.

The authors wish to acknowledge helpful discussions with Andrea M. Jirka (U.S. Environmental Protection Agency, Kansas City), George T. Bowman (State Laboratory of Hygiene, Madison, Wisconsin), and Jack W. Kramer (Water Quality Laboratory, Heidelberg College, Tiffin, Ohio). Additional thanks are due to Jack Kramer, who supplied the highparticulate, agricultural run-off samples (Heidelberg sample) used as controls throughout this work, and to Dr. Ivan Sekerka (National Water Research Institute), and Bertin Francoeur (National Laboratory for Environmental Testing) and Andrea Jirka, who served as colleague reviewers of this report. The help of several other individuals at the National Water Quality Laboratory, Office of Water Quality, and Branch of Systems Analysis also is gratefully acknowledged.

\section{ANALYTICAL METHOD}

\section{Parameter and Codes: \\ Phosphorus, dissolved, I-2610-91 (mg/L as P): 00666 Phosphorus, total, l-4610-91 (mg/L as P): 00665}

\section{Application}

This method is used to determine total phosphorus in water, wastewater, brines, and water-suspended sediment. The suitability of this method for determination of total phosphorus in bottom materials has not been investigated. The analytical range of this method is 0.01 to $2.00 \mathrm{mg} / \mathrm{L}$ of phosphorus. Because a dialyzer is incorporated into the analytical 
cartridge of the continuous flow analyzer used for the colorimetric finish, resolvated digests containing suspended particulates (clays) do not require filtration prior to orthophosphate determinations.

\section{Summary of Method}

2.1 All forms of phosphorus, including organic phosphorus, are converted to orthophosphate ions using reagents and reaction parameters identical to those used in the block digester procedure for determination of organic nitrogen plus ammonia, that is, sulfuric acid, potassium sulfate, and mercury (II) at a temperature of $370^{\circ} \mathrm{C}$.

2.2 The digestion procedure was adapted from the method of Jirka and others (1976), which is identical to USEPA method 365.4 (U.S. Environmental Protection Agency, 1983, p. 365.4-1 to 365.4-3), except that sample and reagent volumes are halved, as is the time required for digestion. Orthophosphate ions originally present in samples along with those released by organophosphorus compounds during the digestion step, are determined colorimetrically by an automated version of the phosphoantimonylmolybdenum blue procedure of Murphy and Riley (1962). The hydrogen ion concentration and $\left[\mathrm{H}^{+}\right]:\left[\mathrm{Mo}^{6+}\right]$ ratio in the analytical stream are $\approx 0.4 M$ and $\approx 74$, respectively, in accordance with optimization experiments of Murphy and Riley (1962) and Pai and others (1990). Continuous flow dialysis, rather than the dilution loop technique of Jirka and others (1976), is used for automated digest dilution and cleanup during the colorimetric finish.

\section{Interferences}

3.1 Sodium chloride is added to the acidic molybdate/antimony reagent to inhibit reduction of $\mathrm{Hg}^{2+}$ in digests to $\mathrm{Hg}^{0}$ by ascorbic acid during the colorimetric finish. Turbidity resulting from this reaction otherwise would interfere.

3.2 Barium, lead, and silver interfere by forming insoluble phosphates, but the effect is usually negligible in natural-water samples. Interference from silicate, which also can form reduced heteropoly acids with molybdate, is negligible under reaction conditions used here.

3.3 Arsenic as arsenate $\left(\mathrm{AsO}_{4}{ }^{-3}\right)$ produces a color similar to that of phosphate and might cause a positive interference. According to Murphy and Riley (1962), concentrations of As (V) up to $100 \mu \mathrm{g} / \mathrm{L}$ do not interfere. 


\section{Instrumentation}

4.1 A third-generation, air-segmented continuous flow analyzer (Alpkem RFA-300) ${ }^{1}$ is used to automate colorimetric determination of orthophosphate ions in resolvated digests. Modules in this system include a 301 sampler, a 302 peristaltic pump, a 313 analytical cartridge base, a 314 power module, a 305A photometer, a 311 recorder, and a PC-based data acquisition and processing system. Alternative procedures to automate the colorimetric finish using flow injection analyzers or other second or third generation continuous flow analyzers also could be implemented.

4.2 The personal computer (PC) used to acquire and process data from the photometric detector must be equipped with a 12-bit, analog-to-digital (A/D) converter plug-in card. This provides resolution of 1 part in 4,095 ( $\approx 0.0012$ volts when 5 volts is full scale), which is conservatively 20 times better than that afforded by a 10 -inch strip-chart recorder. The A/D converter must be able to acquire data at frequencies in the range of 0.5 to $2 \mathrm{~Hz}$, that is, 30 points/min to 120 points/min. As a rule of thumb, data acquisition frequencies for airsegmented continuous flow analyzers should match the roller lift-off frequency of the peristaltic pump, that is, $0.5 \mathrm{~Hz}$ for Technicon AA II and $1.5 \mathrm{~Hz}$ for Alpkem RFA-300 equipment. Most PC-based data acquisition and processing systems sold by vendors of continuous flow analyzers meet or exceed these specifications.

4.3 Operating parameters for this equipment follow.

\begin{tabular}{|c|c|}
\hline Analytical wavelength --------------- & $880 \mathrm{~nm}$ \\
\hline Flow cell path length----- & $15 \mathrm{~mm}$ \\
\hline Standard calibration control & $\approx 4.6$ \\
\hline Dialyzer (H membrane) ------------ & $12 \mathrm{in.}$ \\
\hline Segmentation frequency ------------ & $1.5 \mathrm{~Hz}$ \\
\hline Reaction coil volume------------- & $1 \mathrm{~mL}$ \\
\hline Reaction coil temperature ---- & $37^{\circ} \mathrm{C}$ \\
\hline nalysis rate & $90 / \mathrm{hr}(1$ \\
\hline
\end{tabular}

\section{Apparatus}

5.1 Tecator Digestion System 40, Model 1016 block digesters or equivalent, which accommodate 40, 75-mL tubes, are used to desolvate and digest samples.

1The use of trade, brand, and firm names in this report is for identification purposes only and does not constitute endorsement by the U.S. Geological Survey. 
5.2 In this procedure, block digesters are operated in pairs. Prepared samples are desolvated in one block set at $\approx 220^{\circ} \mathrm{C}$ and immediately digested in another set at $\approx 370^{\circ} \mathrm{C}$. Time required for desolvation is 30 minutes and for digestion is 15 minutes.

\section{Reagents}

\subsection{Digestion reagents}

NOTE: The digestion reagent is formulated to permit determination of Kjeldahl nitrogen as well as total phosphorus in the same digest. Mercury in this reagent catalyzes the breakdown of organic nitrogen compounds, and it can be omitted if resolvated digests are to be determined for total phosphorus only.

CAUTION: Heat is generated when concentrated sulfuric acid is mixed with water. Wear protective eyeglasses, gloves, and clothing. Hot sulfuric acid solutions are hazardous.

6.1.1 Sulfuric acid, 3.6 M: Cautiously add $200 \mathrm{~mL}$ of concentrated sulfuric acid $\left[\mathrm{H}_{2} \mathrm{SO}_{4}\right.$, sp gr 1.84] to $\approx 700 \mathrm{~mL}$ of deionized water contained in a 1-L volumetric flask with constant mixing. Allow this solution to cool, dilute it to the mark with deionized water, and mix it well. Transfer this reagent to a plastic bottle where it is stable indefinitely at room temperature.

6.1.2 Mercury (II) sulfate reagent: Add $25 \mathrm{~mL}$ of $3.6 \mathrm{M}$ sulfuric acid to $4.0 \mathrm{~g}$ of red mercury (II) oxide [ $\mathrm{HgO}, \mathrm{FW}=216.59]$ contained in a $100-\mathrm{mL}$ Griffin beaker. Place the beaker in an ultrasonic bath to speed dissolution. Use the resulting solution immediately to prepare the digestion reagent as described in the next paragraph.

\subsubsection{Digestion reagent: Add $268 \mathrm{~g}$ of potassium sulfate $\left[\mathrm{K}_{2} \mathrm{SO}_{4}\right.$,} $\mathrm{FW}=174.27]$ to $\approx 1,300 \mathrm{~mL}$ of deionized water contained in a $2-\mathrm{L}$ volumetric flask. Cautiously add $400 \mathrm{~mL}$ of concentrated sulfuric acid $\left[\mathrm{H}_{2} \mathrm{SO}_{4}, \mathrm{sp} \mathrm{gr}=1.84\right]$ with constant mixing, and then add the mercury (II) sulfate solution. Stir the mixture magnetically or place the flask in an ultrasonic bath to speed dissolution. Allow this solution to cool, dilute it to the mark with deionized water, and mix it well. Transfer this reagent to a glass bottle or dispensing apparatus, and store it at or above $20^{\circ} \mathrm{C}$ to prevent precipitation of potassium sulfate.

\subsection{Colorimetric reagents}

6.2.1 Sampler wash reservoir solution $\approx 1.3 \mathrm{~N}$ sulfuric acid $+\approx 0.3 \mathrm{M}$ potassium sulfate): Cautiously add $78 \mathrm{~mL}$ of concentrated sulfuric acid $\left[\mathrm{H}_{2} \mathrm{SO}_{4}, \mathrm{sp}\right.$ gr 1.84$]$ to $\approx 1,500$ $\mathrm{mL}$ of deionized water contained in a 2-L volumetric flask with constant mixing. Add $54 \mathrm{~g}$ 
of potassium sulfate $\left[\mathrm{K}_{2} \mathrm{SO}_{4}, \mathrm{FW}=174.27 \mathrm{~g}\right]$, and after it has dissolved, allow the solution to cool. Then dilute it to the mark with deionized water, and mix it well. Transfer this solution to plastic bottles where it is stable indefinitely at room temperature.

NOTE: The hydrogen and sulfate ion concentrations of this solution are similar to those in resolvated digests. It can be used as the matrix for undigested orthophosphate calibrants.

6.2.2 Sodium lauryl sulfate reagent (15 percent $\mathrm{w} / \mathrm{w})$ : Add $60 \mathrm{~g}$ of sodium lauryl sulfate $\left[\mathrm{CH}_{3}\left(\mathrm{CH}_{2}\right)_{11} \mathrm{OSO}_{3} \mathrm{Na}, \mathrm{FW}=288.38\right]$ to $340 \mathrm{~mL}$ of deionized water contained in a 500-mL plastic bottle. Work in a hood because solid sodium lauryl sulfate is a nasal irritant. Cap the bottle and place it in an ultrasonic bath until solution is complete ( $\approx 30$ minutes). Manual inversion of the bottle at 5-minute intervals will speed dissolution. This solution is stable indefinitely at room temperature.

6.2.3 Antimony potassium tartrate reagent: Dissolve $3.0 \mathrm{~g}$ of antimony potassium tartrate $\left[\mathrm{K}(\mathrm{SbO}) \mathrm{C}_{4} \mathrm{H}_{4} \mathrm{O}_{7} \cdot 1 / 2 \mathrm{H}_{2} \mathrm{O}, \mathrm{FW}=333.93\right]$ in $\approx 800 \mathrm{~mL}$ deionized water contained in a 1-L volumetric flask. Dilute this solution to the mark with deionized water and mix it well. Transfer this reagent to a plastic bottle where it is stable indefinitely at room temperature.

6.2.4 Acidic molybdate/antimony reagent (stock): Dissolve $1.0 \mathrm{~g}$ of ammonium molybdate $\left[\left(\mathrm{NH}_{4}\right)_{6} \mathrm{Mo}_{7} \mathrm{O}_{24} \bullet 4 \mathrm{H}_{2} \mathrm{O}, \mathrm{FW}=1235.86\right], 1.0 \mathrm{~g}$ of sodium chloride [ $\mathrm{NaCl}, \mathrm{FW}=$ $58.45]$, and $44 \mathrm{~mL}$ of $3.6 \mathrm{M}$ sulfuric acid in $\approx 800 \mathrm{~mL}$ of deionized water contained in a $1-\mathrm{L}$ volumetric flask. Manually swirl the contents of the flask and add $8.0 \mathrm{~mL}$ of potassium antimony tartrate reagent. Dilute the resulting solution to the mark with deionized water and mix it well. Transfer this reagent to a plastic bottle where it is stable at room temperature for several months.

NOTE: In the dialysis step, there is a net flow of hydrogen ions from the donor stream into the recipient stream. The concentration of sulfuric acid in this reagent--less than that calculated for a hydrogen ion concentration of $0.4 \mathrm{M}$ at the flow cell--is formulated to compensate for this effect.

6.2.5 Acidic molybdate/antimony reagent (working): Transfer 250-mL stock reagent to a plastic bottle and add $5 \mathrm{~mL}$ of sodium lauryl sulfate reagent. Swirl the bottle to mix its contents. Prepare this reagent daily.

\subsubsection{Ascorbic acid reagent (stock): Dissolve $9.0 \mathrm{~g}$ of ascorbic acid} $\left[\mathrm{C}_{6} \mathrm{H}_{8} \mathrm{O}_{6}, \mathrm{FW}=176.13\right]$ in $400 \mathrm{~mL}$ of deionized water contained in a $500-\mathrm{mL}$ volumetric flask. Dilute this solution to the mark with deionized water and mix it well. Store this solution in an amber-colored bottle in a refrigerator, where it is stable for several weeks. 
6.2.7 Ascorbic acid reagent (working): Use a graduated cylinder to dispense $30 \mathrm{~mL}$ of stock ascorbic acid reagent and $70 \mathrm{~mL}$ of deionized water into an amber glass bottle. Swirl the bottle to mix its contents. Prepare this reagent daily.

6.2.8 Diluent: Use a digital microliter $(\mu \mathrm{L})$ pipet to add $100 \mu \mathrm{L}$ of Brij-35 (30 percent w/v) surfactant to $100 \mathrm{~mL}$ of deionized water. (Modified February 25, 2001)

NOTE: Brij-35 surfactant is used in the alkaline donor stream because sodium lauryl sufate (SLS) surfactant precipates. (Modified February 25, 2001)

\section{Calibrants}

7.1 Primary calibrant, phosphorus, inorganic $(1.000 \mathrm{~mL}=0.50 \mathrm{mg} \mathrm{P})$ : Dissolve $1.0985 \mathrm{~g}$ of potassium dihydrogen phosphate $\left[\mathrm{KH}_{2} \mathrm{PO}_{4}, \mathrm{FW}=136.09\right]$ previously dried at $110^{\circ} \mathrm{C}$ for $\approx 2 \mathrm{~h}$ and stored in a desiccator, in $\approx 400 \mathrm{~mL}$ of deionized water contained in a 500 $\mathrm{mL}$ volumetric flask. Dilute this solution to the mark with deionized water and mix it well. Transfer this calibrant to a plastic bottle and store it in a refrigerator where it is stable for several months.

7.2 Primary calibrant, phosphorus, organic $(1.00 \mathrm{~mL}=0.50 \mathrm{mg} \mathrm{P})$ : Dissolve $2.4706 \mathrm{~g}$ of sodium glycerophosphate $\left[\mathrm{C}_{3} \mathrm{H}_{7} \mathrm{O}_{6} \mathrm{PNa}_{2} \cdot 5 \mathrm{H}_{2} \mathrm{O}, \mathrm{FW}=306.1\right]$ in $\approx 400 \mathrm{~mL}$ of deionized water contained in a 500-mL volumetric flask. Dilute this solution to the mark with deionized water and mix it well. Transfer this calibrant to a plastic bottle and store it in a refrigerator where it is stable for several months.

NOTE: When TP and TKN are to be determined in the same digest, prepare a mixed primary calibrant that contains both phosphorus and nitrogen.

7.3 Working calibrants: Use two adjustable pipets (ranges 10-100 $\mu \mathrm{L}$ and $100-1,000 \mu \mathrm{L}$ ) to dispense the volumes of primary calibrant, listed in table 1 , and $1.000 \mathrm{~mL}$ of field preservative solution $\left(1.3 \mathrm{~g} \mathrm{HgCl}_{2}+10.0 \mathrm{~g} \mathrm{NaCl}\right.$ in $100 \mathrm{~mL}$ of deionized water) into a series of 250 -mL volumetric flasks that each contain $\approx 240 \mathrm{~mL}$ of deionized water. These flasks should be rinsed with a dilute solution of hydrochloric acid $(\approx 5$ percent $\mathrm{v} / \mathrm{v}$ ) and deionized water just prior to calibrant preparation. Dilute the contents of the flasks to the mark with deionized water, and shake them with repeated inversion to ensure thorough mixing. Transfer calibrants to plastic bottles and store them in a refrigerator when they are not in use. Prepare working calibrants as needed or biweekly, whichever comes first.

NOTE: Undigested calibrants, which are useful for assessing instrument function, can be prepared from the primary orthophosphate calibrant using the sampler wash reservoir solution (see section 6) as the matrix. 
Table 1. Calibrant preparation protocol

$[\mu \mathrm{L}$, microliter; $\mathrm{mg} / \mathrm{L}$, milligram per liter]

\begin{tabular}{|c|c|c|c|}
\hline $\begin{array}{c}\text { Calibrant } \\
\text { identification }\end{array}$ & $\begin{array}{c}\text { Primary } \\
\text { calibrant } \\
\text { volume }(\mu \mathrm{L})\end{array}$ & $\begin{array}{c}\text { Field } \\
\text { preservative } \\
\text { volume }(\mu \mathrm{L}) \\
\end{array}$ & $\begin{array}{c}\text { Nominal } \\
\text { concentration } 1 \\
(\mathrm{mg} / \mathrm{L}) \\
\end{array}$ \\
\hline $\mathrm{C} 1$ & 1,000 & 1,000 & 2.00 \\
\hline $\mathrm{C} 2$ & 500 & 1,000 & 1.00 \\
\hline $\mathrm{C} 3$ & 250 & 1,000 & .50 \\
\hline $\mathrm{C} 4$ & 125 & 1,000 & .25 \\
\hline $\mathrm{C} 5$ & 50 & 1,000 & .10 \\
\hline C6 & 10 & 1,000 & .02 \\
\hline (Blank) & 0 & 1,000 & .00 \\
\hline
\end{tabular}

${ }^{1}$ Based on a final volume of $250 \mathrm{~mL}$.

\section{Sample Preparation}

8.1 Dispense calibrants, blanks (generally, deionized water is used), reference materials, and samples into digestion tubes as follows. Note that three positions in each block are reserved for duplicate and spike determinations.

8.1.1 Rinse all glassware with a dilute solution of hydrochloric acid $(\approx 5$ percent $\mathrm{v} / \mathrm{v})$ and deionized water before each use.

8.1.2 Use an adjustable (5.0 to $10.0 \mathrm{~mL}$ ) pipet to dispense $10.0-\mathrm{mL}$ aliquots of calibrant, blank, reference, and sample solutions into digestion tubes. The suggested block protocol can be found in table 2. Vigorously shake sample containers and immediately aspirate aliquots to avoid sampling errors. When samples contain large quantities of suspended solids, continuous stirring or sonication during sample aspiration might provide the only means of obtaining representative aliquots.

8.1.3 Use an adjustable (1-5 mL) pipet to dispense $2.00 \mathrm{~mL}$ of digestion reagent into each tube. Then add several Teflon boiling chips to each tube.

8.1.4 Desolvate prepared digests under a hood for 30 minutes in the block digester set at $220^{\circ} \mathrm{C}$.

8.1.5 Immediately transfer (CAUTION!) desolvated digests to the block digester set at $370^{\circ} \mathrm{C}$, and leave them there for 15 minutes.

8.1.6 Cautiously remove digestion tubes from the block digester and allow them to cool for $\approx 10$ minutes in the hood. With extreme caution, immediately dispense $10.0 \mathrm{~mL}$ of deionized water into each tube with vigorous agitation, using an adjustable $(5-10 \mathrm{~mL})$ pipet and a vortex mixer. 
Table 2. Suggested block protocol for determination of total phosphorus by methods I-2610/4610-91 [ID, identification]

\begin{tabular}{cccccc}
\hline $\begin{array}{c}\text { Block } \\
\text { position }\end{array}$ & $\begin{array}{c}\text { Sample } \\
\text { ID }\end{array}$ & $\begin{array}{c}\text { Block } \\
\text { position }\end{array}$ & $\begin{array}{c}\text { Sample } \\
\text { ID }\end{array}$ & $\begin{array}{c}\text { Block } \\
\text { position }\end{array}$ & $\begin{array}{c}\text { Sample } \\
\text { ID }\end{array}$ \\
\hline 1 & C1 & 15 & SAMPLE & 29 & SAMPLE \\
2 & C2 & 16 & SRWS & 30 & SAMPLE \\
3 & C3 & 17 & SAMPLE & 31 & SAMPLE \\
4 & C4 & 18 & SAMPLE & 32 & BLANK \\
5 & C5 & 19 & SAMPLE & 33 & SAMPLE \\
6 & C6 & 20 & SAMPLE & 34 & SAMPLE \\
7 & ORG_CHK & 21 & SAMPLE & 35 & SAMPLE \\
8 & BLANK & 22 & SAMPLE & 36 & SAMPLE \\
9 & SAMPLE & 23 & SAMPLE & 37 & SAMPLE \\
10 & SAMPLE & 24 & SRWS & 38 & SPIKE 2 \\
11 & SAMPLE & 25 & SAMPLE & 39 & DUPLICATE 2 \\
12 & SAMPLE & 26 & SAMPLE & 40 & DUPLICATE \\
13 & SAMPLE & 27 & SAMPLE & & \\
14 & SAMPLE & 28 & SAMPLE & & \\
\hline
\end{tabular}

${ }^{1}$ A solution of $1.5 \mathrm{mg} / \mathrm{L}$ (as $\mathrm{P}$ ) sodium glycerophosphate is recommended.

${ }^{2}$ Samples for spiking and duplicate determinations should be chosen randomly.

\section{Instrument Performance}

When a pair of block digesters is used as described in the introduction, 40 calibrants, reference waters, and samples can be digested and resolvated in about an hour. The air-segmented continuous flow analyzer used in this method can perform 90 orthophosphate determinations an hour with less than 1 percent interaction. Thus, a single channel analyzer can process the resolvated digests from two pairs of block digesters each hour.

\section{Calibration}

With a second-order polynomial $\left(y=a+b x+c x^{2}\right.$, where $y=$ corrected peak height and $x=$ concentration) least-squares curve-fitting algorithm, the correlation coefficient of the calibration plot should be greater than 0.999. A typical calibration plot for total phosphorus calibrants in the concentration range of 0.10 to $2.00 \mathrm{mg} / \mathrm{L}$ is shown in figure 1 . Note that digestion blank corrections must be applied to both calibrants and samples prior to calculation of final results as described under sections 12.3 and 12.4. 


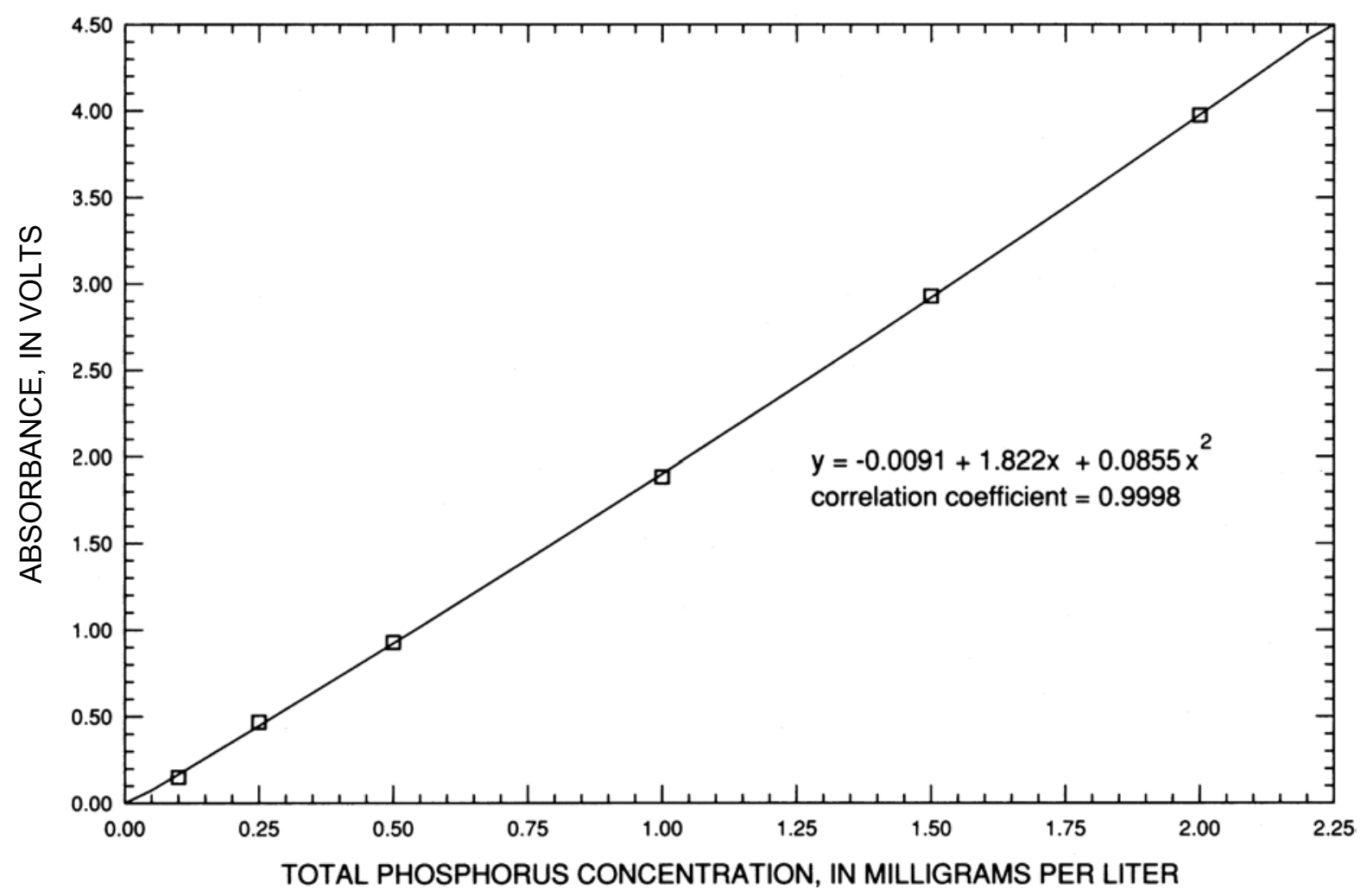

Figure 1. Typical calibration plot for determination of orthophosphate in digests prepared by methods I-2610/4610-91.

\section{Procedure and Data Evaluation}

Set up the analytical cartridge of the continuous flow analyzer as shown in figure 2 . Turn on electrical power to all system modules and put fresh sampler wash reservoir solution and reagents on-line. After about 10 minutes, verify that the output of sample and reference detectors is $\approx 5$ volts. This method should not require daily adjustment of the STD CAL control, that is, absorbance units full scale or sensitivity. Between-run/between-day variations in baseline-absorbance level and calibration curve slope of $\approx \pm 5$ percent are acceptable. Adjustment of the STD CAL control to compensate for larger variations in sensitivity or baseline (reagent blank) levels will only mask underlying problems such as incipient light source failure, partially clogged flow cells, or contaminated or improperly prepared reagents, any of which could compromise analytical results. A suggested sampler tray protocol for automated determination of orthophosphate in resolvated digests is shown in table 3. 


\section{EXPLANATION}

1) Dual injection fitting, Alpkem P/N 303-0107

2 12-inch dialyzer assembly, Alpkem P/N 303-0805

3 Dialysis membrane, "H" type, Alpkem P/N 303-0807P00, or equivalent. A 45 inch-pound torque wrench, Bran Luebbe P/N 178-5121-01, is needed to tighten the dialyzer plates sufficiently to seal the membrane.

Color Code

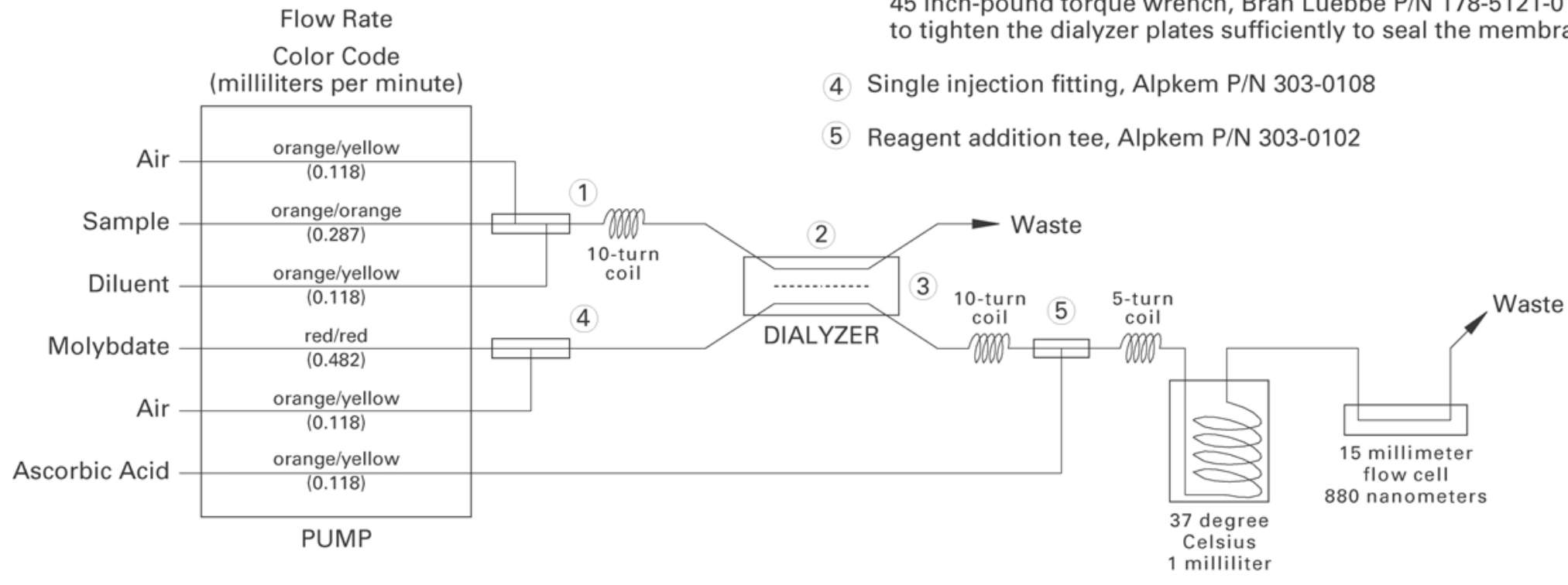

NOTE: Diluent $-100 \mu \mathrm{L}$ Brij-35 per $100 \mathrm{~mL}$ ASTM Type I Deionized Water

Figure 2. Analytical cartridge diagram for determination of total phosphorus concentration by methods I-2610/4610-91. 
Table 3. Suggested tray protocol for automated determination of orthophosphate in resolvated digests by methods I-2610/4610-91

[ID, identification]

\begin{tabular}{cccccc}
\hline $\begin{array}{c}\text { Cup } \\
\text { number }\end{array}$ & $\begin{array}{c}\text { Sample } \\
\text { ID }\end{array}$ & $\begin{array}{c}\text { Cup } \\
\text { number }\end{array}$ & $\begin{array}{c}\text { Sample } \\
\text { ID }\end{array}$ & $\begin{array}{c}\text { Cup } \\
\text { number }\end{array}$ & $\begin{array}{c}\text { Sample } \\
\text { ID }\end{array}$ \\
\hline 1 & SYNC $(\mathrm{C} 1)$ & 15 & SAMPLE & 29 & SAMPLE \\
2 & C1 & 16 & SAMPLE & 30 & SAMPLE \\
3 & C2 & 17 & SRWS & 31 & SAMPLE \\
4 & C3 & 18 & SAMPLE & 32 & SAMPLE \\
5 & C4 & 19 & SAMPLE & 33 & SAMPLE \\
6 & C5 & 20 & SAMPLE & 34 & SAMPLE \\
7 & C6 & 21 & SAMPLE & 35 & SAMPLE \\
8 & U_BLANK 1 & 22 & SAMPLE & 36 & SAMPLE \\
9 & BLANK & 23 & SAMPLE & 37 & SAMPLE \\
10 & BLANK & 24 & SAMPLE & 38 & SAMPLE \\
11 & ORG_CHK & 25 & SRWS & 39 & SAMPLE \\
12 & SAMPLE & 26 & SAMPLE & 40 & SPIKE \\
13 & SAMPLE & 27 & SAMPLE & 41 & DUPLICATE \\
14 & SAMPLE & 28 & SAMPLE & 42 & DUPLICATE \\
\hline
\end{tabular}

${ }^{1} U_{-}$BLANK (sampler wash reservoir solution, see 6.2.1) is an undigested blank.

${ }^{2}$ Organic phosphorus check sample; see note 2 on table 2.

NOTE: To minimize errors resulting from contaminated analyzer cups, rinse them several times with the solution they are to contain before placing them on the analyzer sampler tray.

\section{Calculations}

12.1 Instrument calibration requires the preparation of a set of solutions (calibrants) in which the analyte concentration is known. These calibrants are digested along with samples and used to establish a calibration function that is estimated from a least-squares fit of nominal calibrant concentrations $(x)$ and peak absorbencies $(y)$. A second-order polynomial function $\left(y=a+b x+c x^{2}\right)$ usually provides improved concentration estimates at calibration range extremes than the more conventional linear model $(y=a+b x)$. There is no loss of accuracy when a second-order fit is used even if the calibration function is strictly linear, because the value estimated for the quadratic parameter will approach zero.

12.2 Before the calibration function can be estimated, the baseline absorbance component of measured peak heights including drift (continuous increase or decrease in the baseline absorbance during the course of a run), if present, needs to be removed. Baseline 
absorbance in continuous flow analysis is analogous to the reagent blank absorbance in batch analysis. Correction for baseline absorbance is an automatic function of most data acquisition and processing software sold by vendors of continuous flow analyzers. These correction algorithms, however, are based on linear interpolation between initial and intermediate or final values, and so do not accurately correct for abrupt, step-changes in baseline absorbance that usually indicate partial flow cell blockage. It is prudent, therefore, to reestablish baseline absorbance at intervals of 20 samples or so.

12.3 After peaks are baseline corrected, they need to be digestion blank corrected. This correction can be applied in two ways. In one method, the baseline-corrected blank absorbance is subtracted from the baseline-corrected absorbance of samples and calibrants. Then regression parameters ( $a, b$, and $c$ terms) for the calibration function are estimated using a second-order polynomial least-squares algorithm. A Newton-Raphson, successive approximations algorithm (Draper and Smith, 1966; Swartz, 1976, 1977, 1979) should be used to convert peak heights into concentrations for second and higher order calibration functions.

12.4 In the other method, the digestion blank is designated as a calibrant with a nominal concentration of zero. The calibration function estimated as described in section 12.3 then will have a positive y-intercept, the magnitude of which will approximate the baselinecorrected absorbance of the digestion blank. If this method is used, be sure that the curvefitting algorithm does not force a zero y-intercept by including one or more "dummy" $(0,0)$ points in the data set used for calibration. Analytical results calculated by either method should be equivalent, so choose the one that is most easily implemented with the software available.

NOTE: In older software packages, the expedient of reversing the roles of independent $(x)$ and dependent $(y)$ variables to estimate concentrations from peak heights for second and higher order calibration functions was common. This practice might compromise accuracy of analytical results, especially those estimated at the extremes of the calibration range, and can confuse efforts to compare methods and data sets from different eras or laboratories. Make sure that all algorithms in the software package used are understood thoroughly and on file with standard operation procedures.

12.5 Most software packages provide a data base into which appropriate dilution factors can be entered. Usually these factors can be entered before or after a run is performed. If dilution factors are entered, reported values will be compensated automatically for the extent of dilution. The dilution factor simply is the number by which measured concentrations need 
to be multiplied to reflect the concentration of analyte in the sample prior to dilution. For example, if sample and diluent are combined in proportions of $1+1,1+4$, and $1+9$, the dilution factors are 2,5 , and 10 , respectively.

\section{Report}

Report phosphorus, dissolved (00666) and total (00665), concentrations as follows: less than $2.0 \mathrm{mg} / \mathrm{L}$, two decimals; $2.0 \mathrm{mg} / \mathrm{L}$ and above, two significant figures.

\section{Precision and Bias}

14.1 Within-run precision (repeatability) for methods I-2610/4610-91 on the basis of 55 replicate determinations of a sample high in suspended solids (Heidelberg) was 0.70 percent. The average phosphorus concentration determined for this run was $1.55 \mathrm{mg} / \mathrm{L}$. Between-day precision on the basis of 26 replicate determinations of the same sample between April 8 and April 26, 1991, was 5.00 percent. The average phosphorus concentration determined for these replicates was $1.60 \mathrm{mg} / \mathrm{L}$.

14.2 Paired $t$-test analysis of $\approx 1,600$ samples determined for TP by methods I-2600/4600-85 and methods I-2610/4610-91 revealed a positive bias in the range of 0.02 to $0.04 \mathrm{mg} / \mathrm{L}$ for the latter. Positive bias of this extent was expected and is in agreement with a previous study by Jirka and others (1976) who compared their Kjeldahl method with USEPA's persulfate digestion method 365.1. These workers suggested that the bias was real and resulted from the more rigorous reaction conditions of the Kjeldahl digestion relative to the persulfate digestion. Complete details of the method comparison studies can be found in the Discussion of Results section that follows.

\section{DISCUSSION OF RESULTS}

Two blanks were digested in each block during the course of both studies (April 1991; July to September 1991). The average and standard deviations of 82 blanks determined by methods I-2610/4610-91 during the April study were $0.01 \mathrm{mg} / \mathrm{L} \pm 0.01 \mathrm{mg} / \mathrm{L}$. This concentration is significant because it is equivalent to the method detection limit. Therefore, peak heights (baseline-corrected absorbances) of all calibrants, reference materials, and samples were blank corrected prior to estimation of calibration functions and analytical concentrations. A plot of the blank concentrations determined by methods I-2610/4610-91 for total phosphorus as a function of Julian date is shown in figure 3. 


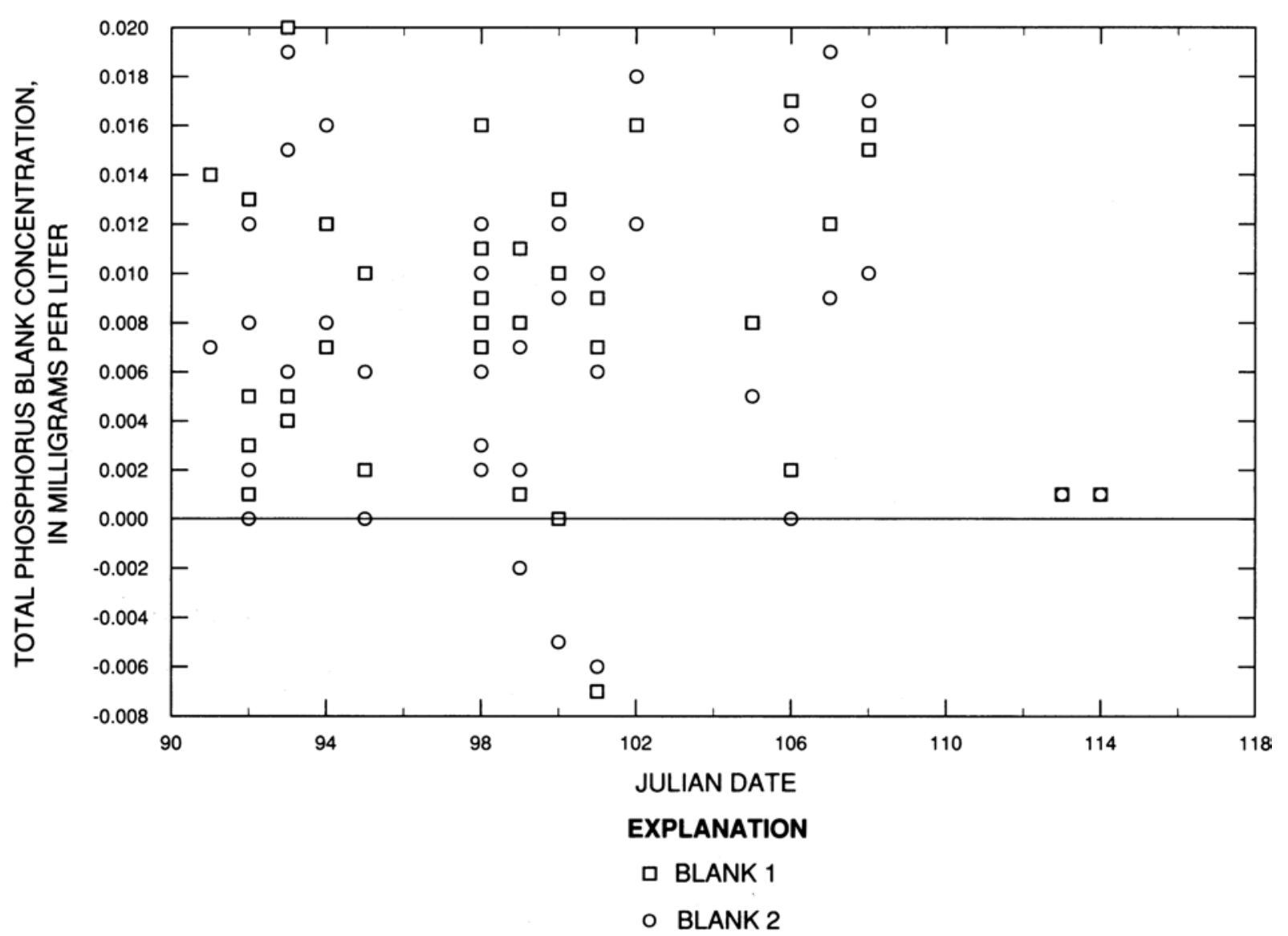

Figure 3. Total phosphorus blank concentrations determined by methodsl-2610/4610-91 during the April 1991 experiment.

The average and standard deviations of 44 blanks determined by methods $\mathrm{I}-2600 / 4600-85$ during the same period was $0.003 \mathrm{mg} / \mathrm{L} \pm 0.002 \mathrm{mg} / \mathrm{L}$. This concentration is negligible, and, therefore, blank corrections were not necessary. A plot of blank concentrations determined by methods I-2600/4600-85 for total phosphorus as a function of Julian date is shown in figure 4. Note that two nominally identical continuous flow analyzers were used for colorimetric determinations in methods I-2600/4600-85. Thus "Channel 3" and "Channel 4" in figure 4 refer to blank values determined by one or the other of the two analyzers.

A method detection limit (MDL) of $\approx 0.01 \mathrm{mg} / \mathrm{L}$ was estimated for methods I-2610/4610-91 using the protocol set forth in the U.S. Code of Federal Regulations (1990). Note that although the analytical range of the colorimetric finish for methods I-2610/4610-91 is twice that of the one used with methods I-2600/4600-85, the MDL of the former is adequate for existing reporting limits. Additional details are shown in table 4. 


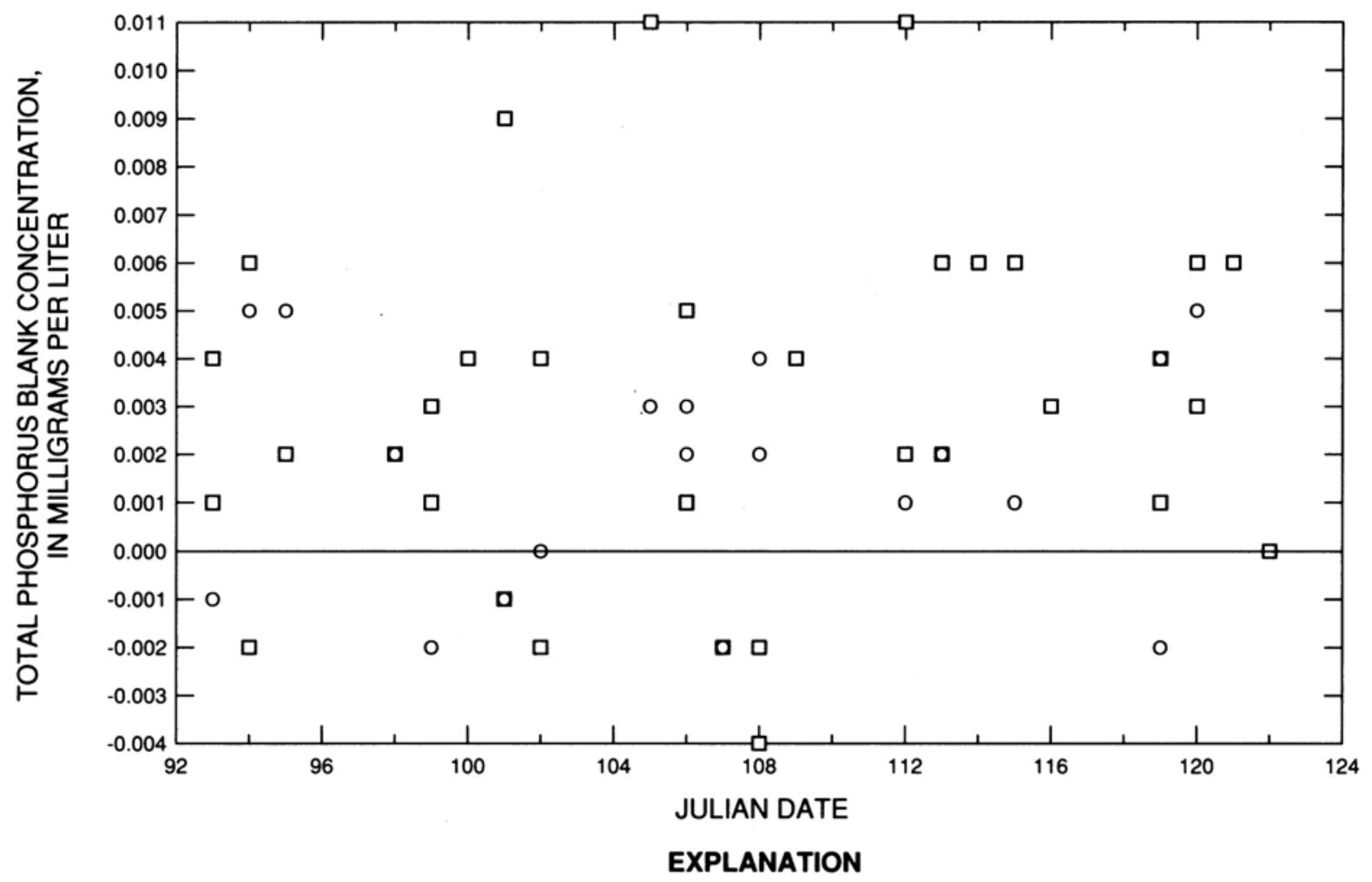

口 CHANNEL 3

- CHANNEL 4

Figure 4. Total phosphorus blank concentrations determined by methodsl-2600/4600-85 during the April 1991 experiment.

Prior to statistical analysis, both the April and July through September data sets were sorted by sample type into four groups: filtered (FC bottle) and unfiltered (RC bottle) surface water; filtered and unfiltered ground water.

For both data sets, paired $t$-test analysis of total phosphorus (TP) concentrations in surface-water samples revealed a small positive bias in concentration values determined by methods I-2610/4610-91. When means for the entire concentration range in each group were compared, a positive bias of about $0.02 \mathrm{mg} / \mathrm{L}$ was estimated for filtered surface-water samples and $0.04 \mathrm{mg} / \mathrm{L}$ for unfiltered surface-water samples. Only in the case of filtered surface-water samples in the April data set was the estimated bias not significant at the $p=0.05$ level. Dividing groups into multiple concentration ranges revealed the general trend that for both filtered and unfiltered samples, positive bias in concentration values determined by methods I-2610/4610-91 increased as the TP concentration increased. In the July through 
Table 4. Data used to estimate the method detection limit (MDL) for total phosphorus determination by methods I-2610/4610-91

[Measured concentrations pertain to eight replicate digestions of a $0.05 \mathrm{mg} / \mathrm{L}$ (milligram per liter) glycerophosphate calibrant, which was prepared in deionized water containing an appropriate volume of field preservative solution]

\begin{tabular}{|c|c|c|}
\hline $\begin{array}{l}\text { Replicate } \\
\text { number }\end{array}$ & $\begin{array}{c}\text { Nominal } \\
\text { concentration }(\mathrm{mg} / \mathrm{L})\end{array}$ & $\begin{array}{c}\text { Measured } \\
\text { concentration }(\mathrm{mg} / \mathrm{L})\end{array}$ \\
\hline 1 & 0.05 & 0.050 \\
\hline 2 & .05 & .056 \\
\hline 3 & .05 & .051 \\
\hline 4 & .05 & .053 \\
\hline 5 & .05 & .046 \\
\hline 6 & .05 & .057 \\
\hline 7 & .05 & .047 \\
\hline 8 & .05 & .046 \\
\hline & $\begin{array}{l}\text { Average }(\mathrm{mg} / \mathrm{L}) \\
\text { Standard deviation }(\mathrm{mg} / \mathrm{L}) \\
\text { Number of points } \\
\text { Degrees of freedom } \\
t \text { value }(99=\text { percent confidence) } \\
\text { MDL }\end{array}$ & $\begin{array}{l}=0.051 \\
=0.004 \\
=8 \\
=7 \\
=2.998 \\
=0.012\end{array}$ \\
\hline
\end{tabular}

September data sets, for example, a positive bias of $0.33 \mathrm{mg} / \mathrm{L}$ was estimated for the 16 samples in the concentration range of 2.00 to $4.50 \mathrm{mg} / \mathrm{L}$, while a positive bias of only 0.01 $\mathrm{mg} / \mathrm{L}$ was estimated for the 352 samples in the concentration range of 0.00 to $0.15 \mathrm{mg} / \mathrm{L}$. This trend-positive bias in methods I-2610/4610-91 increases relative to methods I-2600/4600-85 as TP concentration increases - is consistent with reagent limitation in methods I-2600/4600-85 (U.S. Geological Survey, Office of Water Quality Technical Memorandum No. 92.10, 1992). As described in Rickert's memorandum, digestion reagent concentrations in methods I-2600/I-4600 were identical to those specified in USEPA method 365.1. Sometime after 1973 during a method rewrite, however, a miscalculation or typographical error was introduced into methods I-2600/4600, which resulted in a digestion reagent with persulfate ion and sulfuric acid concentrations 15 and 1.7 times less than those specified in the USEPA method. This error was not detected until 1989. The report (D.A. Rickert, U.S. Geological Survey, written commun., 1992) provides convincing statistical evidence that TP concentrations determined by methods I-2600/I-4600 are biased low for samples with high concentrations of suspended sediment, or organic carbon, or both. Samples in these categories represent about 10 percent of all those received at the NWQL for TP determinations each year. Complete results of paired $t$-test analysis for surface-water samples are shown in tables 5 through 8 . Scatter plots for filtered and unfiltered surfacewater samples are shown in figures 5 and 6. (Page modified: April 28, 2003.) 
For ground water $(\approx 10$ percent of all samples in the April data set; $\approx 5$ percent of all samples in the July through September data sets), on the other hand, the means of concentration values determined by methods I-2600/4600-85 and methods I-2610/4610-91 were statistically equivalent at the $p=0.05$ level. This result is consistent with low TP concentrations and small sample populations of these data sets. (See USGS Office of Water Quality Technical Memorandum 92.10 entitled, "Programs and Plans--Phosphorus Methods and the Quality of Phosphorus Data," which the author will make available on request.) Complete results of paired $t$-test analysis for ground-water samples are shown in tables 9 and 10. A scatter plot for filtered and unfiltered samples is shown in figure 7.

In methods I-2610/4610-91, a dialyzer, equipped with an "H" membrane, was incorporated into the analytical cartridge of the continuous flow analyzer to remove particulates that would otherwise interfere with the colorimetric determination of orthophosphate in resolvated digests. This membrane was effective as shown by data presented in table 11 and in figure 8. Analytical results for the Heidelberg sample, the resolvated digests of which were highly turbid, were not altered by passage through a 0.45 $\mu \mathrm{m}$ nylon syringe filter. There was no indication of surface fouling or mechanical failure of the dialysis membrane during the course of this work, and photometer flow-cell clogging was never a problem. Furthermore, the consensus TP concentration $(\approx 1.6 \mathrm{mg} / \mathrm{L})$ for the Heidelberg sample routinely was determined by methods I-2610/4610-91 without recourse to $1+9$ dilution prior to digestion. This is an improvement over methods I-2600/4600-85.

Recovery of phosphorus from a sample high in suspended solids and a solution of adenosin 5' triphosphate (ATP) as a function of digestion time is shown in figure 9. With reference to figure 9 , it can be seen that the 15-minute high-temperature digestion step is adequate to convert all organic phosphorus in the natural and synthetic samples into orthophosphate ions.

Repeatability (within-run precision) as estimated from 55 replicate determinations of the Heidelberg sample was 0.7 percent. A plot of these data is shown in figure 10, and values for each point are shown in table 12. Between-day precision for digested calibrants and the Heidelberg sample is shown in table 13. Relative values of standard deviation in the range of 1 to 7 percent increased as total phosphorus concentration decreased. A summary of between-day accuracy assessments on the basis of values determined for reference materials provided by the USEPA and the USGS is shown in table 14. In all cases, concentrations determined by methods I-2610/4610-91 for these reference materials were within control 
Table 5. Paired $t$-test analysis of total phosphorus (TP) concentrations in filtered surface-water samples determined by methods $1-2600 / 4600-85$ (variable 1) and methods I-2610/4610-91 (variable 2) for the April 1991 experiment

[Negative values in the right-most column indicate the extent to which TP concentrations determined by methods I-2610/4610-91 exceeded those determined by methods I-2600/4600-85. See text for further details. mg/L, milligram per liter; $p$, probability level]

\begin{tabular}{cccccc}
\hline $\begin{array}{c}\text { Concentration } \\
\text { range } \\
(\mathbf{m g} / \mathbf{L})\end{array}$ & $\begin{array}{c}\text { Degrees of } \\
\text { freedom }\end{array}$ & $\begin{array}{c}\text { Two-sided } \\
\text { significance } \\
\text { level }\end{array}$ & $\begin{array}{c}\text { Reject null } \\
\text { hypothesis } \\
\text { at } \boldsymbol{p}=\mathbf{0 . 0 5}\end{array}$ & $\begin{array}{c}\text { t-Statistic } \\
\text { (calculated) }\end{array}$ & $\begin{array}{c}\text { Difference between } \\
\text { means } \\
\text { (mg/L) }\end{array}$ \\
\hline $0.00-1.00$ & 45 & 0.4616 & No & -0.7425116 & -0.01 \\
$0.00-0.21$ & 40 & 0.2269 & No & -1.227739 & -0.01 \\
$0.22-0.93$ & 5 & 0.8907 & No & 0.1445316 & 0.0 \\
\hline
\end{tabular}


Table 6. Paired $t$-test analysis of total phosphorus (TP) concentrations in filtered surface-water samples determined by methods I-2600/4600-85 (variable 1) and methods I-2610/4610-91 (variable 2) for the July through September 1991 experiments

[Negative values in the right-most column indicate the extent to which TP concentrations determined by methods I-2610/4610-91 exceeded those determined by methods I-2600/4600-85. See text for further details. mg/L, milligram per liter; $p$, probability level]

\begin{tabular}{cccccc}
\hline $\begin{array}{c}\text { Concentration } \\
\text { range } \\
\text { (mg/L) }\end{array}$ & $\begin{array}{c}\text { Degrees of } \\
\text { freedom }\end{array}$ & $\begin{array}{c}\text { Two-sided } \\
\text { significance } \\
\text { level }\end{array}$ & $\begin{array}{c}\text { Reject null } \\
\text { hypothesis } \\
\text { at } \boldsymbol{p}=\mathbf{0 . 0 5}\end{array}$ & $\begin{array}{c}\boldsymbol{t} \text {-Statistic } \\
\text { (calculated) }\end{array}$ & $\begin{array}{c}\text { Difference between } \\
\text { means } \\
\text { (mg/L) }\end{array}$ \\
\hline $0.00-4.00$ & 493 & 0.0000 & Yes & -5.764166 & -0.02 \\
$2.00-4.00$ & 14 & 0.0009 & Yes & -4.21093 & -0.24 \\
$1.00-2.00$ & 14 & 0.0001 & Yes & -5.305076 & -0.17 \\
$0.70-1.00$ & 9 & 0.0010 & Yes & -4.776996 & -0.12 \\
& & & & & -11.0879 \\
$0.50-0.70$ & 9 & 0.0000 & Yes & -7.759562 & -0.07 \\
$0.30-0.50$ & 19 & 0.0000 & Yes & -3.286368 & -0.04 \\
$0.15-0.30$ & 46 & 0.0019 & Yes & -1.843764 & -0.00 \\
$0.00-0.15$ & 374 & 0.0652 & No & & \\
\hline
\end{tabular}


Table 7. Paired $t$-test analysis of total phosphorus (TP) concentrations in unfiltered surface-water samples determined by methods I-2600/4600-85 (variable 1) and methods I-2610/4610-91 (variable 2) for the April 1991 experiment

[Negative values in the right-most column indicate the extent to which TP concentrations determined by methods I-2610/4610-91 exceeded those determined by methods I-2600/4600-85. See text for further details. mg/L, milligram per liter; $p$, probability level]

\begin{tabular}{cccccc}
\hline $\begin{array}{c}\text { Concentration } \\
\text { range } \\
(\mathbf{m g} / \mathbf{L})\end{array}$ & $\begin{array}{c}\text { Degrees of } \\
\text { freedom }\end{array}$ & $\begin{array}{c}\text { Two-sided } \\
\text { significance } \\
\text { level }\end{array}$ & $\begin{array}{c}\text { Reject null } \\
\text { hypothesis } \\
\text { at } \boldsymbol{p}=\mathbf{0 . 0 5}\end{array}$ & $\begin{array}{c}\boldsymbol{t} \text {-Statistic } \\
\text { (calculated) }\end{array}$ & $\begin{array}{c}\text { Difference } \\
\text { between means } \\
\text { (mg/L) }\end{array}$ \\
\hline $0.00-3.00$ & 318 & 0.0000 & Yes & -6.364469 & -0.03 \\
$0.50-3.00$ & 23 & 0.0364 & Yes & -2.222168 & -0.11 \\
$0.30-0.50$ & 22 & 0.0478 & Yes & -2.095601 & -0.04 \\
$0.15-0.30$ & 62 & 0.0000 & Yes & -5.54443 & -0.04 \\
$0.00-0.15$ & 208 & 0.0000 & Yes & -7.205574 & -0.02 \\
\hline
\end{tabular}


Table 8. Paired $t$-test analysis of total phosphorus (TP) concentrations in unfiltered surface-water samples determined by methods I-2600/4600-85 (variable 1) and methods I-2610/4610-91 (variable 2) for the July through September 1991 experiments

[Negative values in the right-most column indicate the extent to which TP concentrations determined by methods I-2610/4610-91 exceeded those determined by methods I-2600/4600-85. See text for further details. mg/L, milligram per liter; $p$, probability level]

\begin{tabular}{cccccc}
\hline $\begin{array}{c}\text { Concentration } \\
\text { range } \\
\text { (mg/L) }\end{array}$ & $\begin{array}{c}\text { Degrees of } \\
\text { freedom }\end{array}$ & $\begin{array}{c}\text { Two-sided } \\
\text { significance } \\
\text { level }\end{array}$ & $\begin{array}{c}\text { Reject null } \\
\text { hypothesis } \\
\text { at } \boldsymbol{p}=\mathbf{0 . 0 5}\end{array}$ & $\begin{array}{c}\text { t-Statistic } \\
\text { (calculated) }\end{array}$ & $\begin{array}{c}\text { Difference } \\
\text { between } \text { means } \\
\text { (mg/L) }\end{array}$ \\
\hline $0.00-4.50$ & 601 & 0.0000 & Yes & -9.39205 & -0.04 \\
$2.00-4.50$ & 16 & 0.0000 & Yes & -8.015939 & -0.33 \\
$1.00-2.00$ & 25 & 0.0008 & Yes & -3.813155 & -0.13 \\
$0.70-1.00$ & 25 & 0.0098 & Yes & -2.797909 & -0.12 \\
& & & & & -0.07 \\
$0.50-0.70$ & 18 & 0.0001 & Yes & -5.037601 & -0.05 \\
$0.30-0.50$ & 58 & 0.0000 & Yes & -4.924593 & -0.05 \\
$0.15-0.30$ & 106 & 0.0000 & Yes & -4.36489 & -0.01 \\
$0.00-0.15$ & 352 & 0.0136 & Yes & -2.467834 & \\
\hline
\end{tabular}




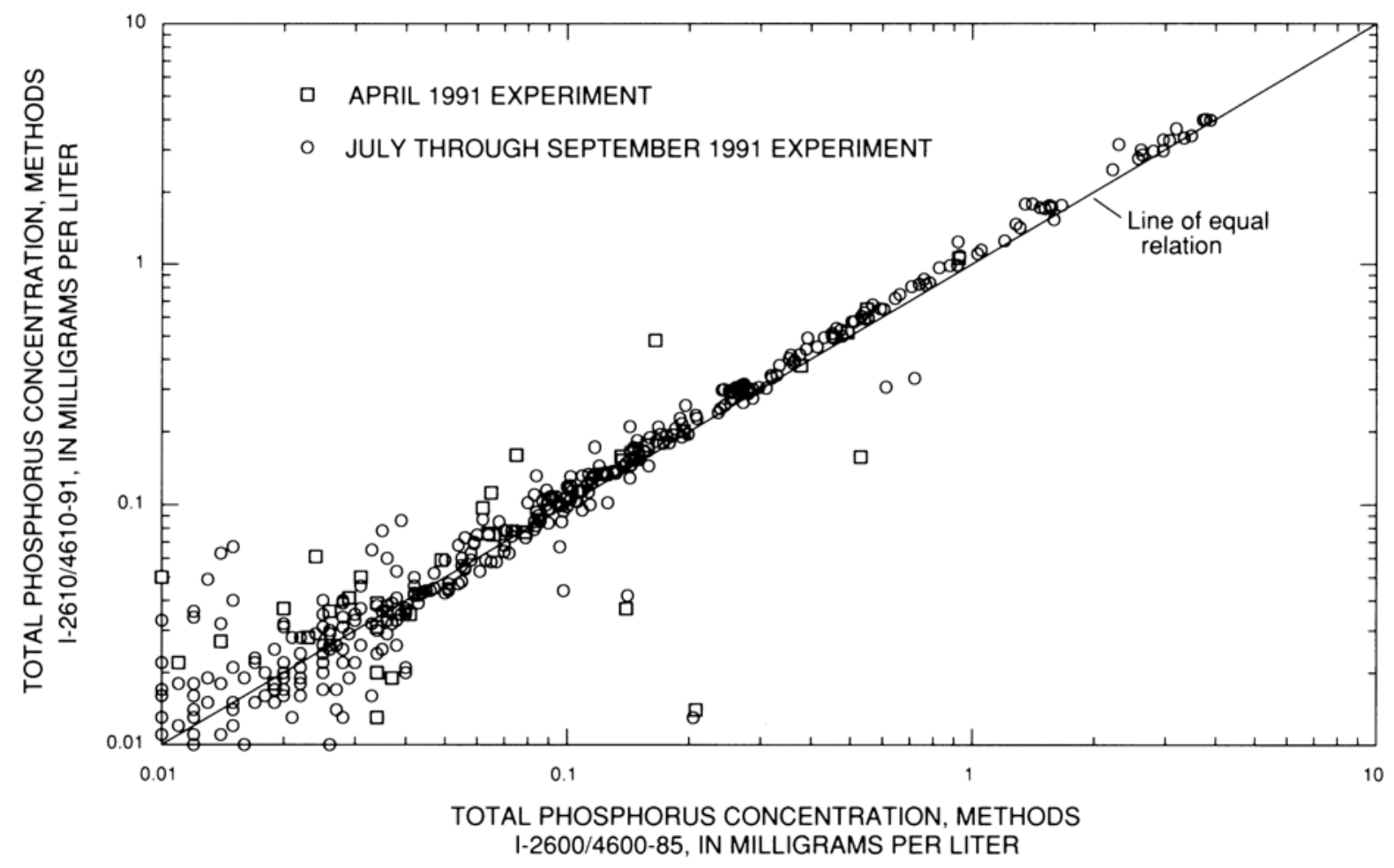

Figure 5. Relation between total phosphorus concentrations determined in filtered surface-water samples by methods I-2600/4600-85 and total phosphorus concentrations determined by methods I-2610/4610-91.

limits. The average recovery for orthophosphate in 73 samples selected randomly and spiked at a concentration level of $0.20 \mathrm{mg} / \mathrm{L}$ was $\approx 95$ percent. Additional details follow in the Quality Assurance section.

\section{QUALITY ASSURANCE}

In addition to USGS Standard Reference Waters and an organic check standard (adenosin 5' triphosphate or sodium glycerophosphate), three samples in each block should be prepared in duplicate. Spike one of these samples at a concentration level of $0.20 \mathrm{mg} / \mathrm{L}$ with inorganic or organic phosphorus. Choose these samples randomly from each worksheet. 


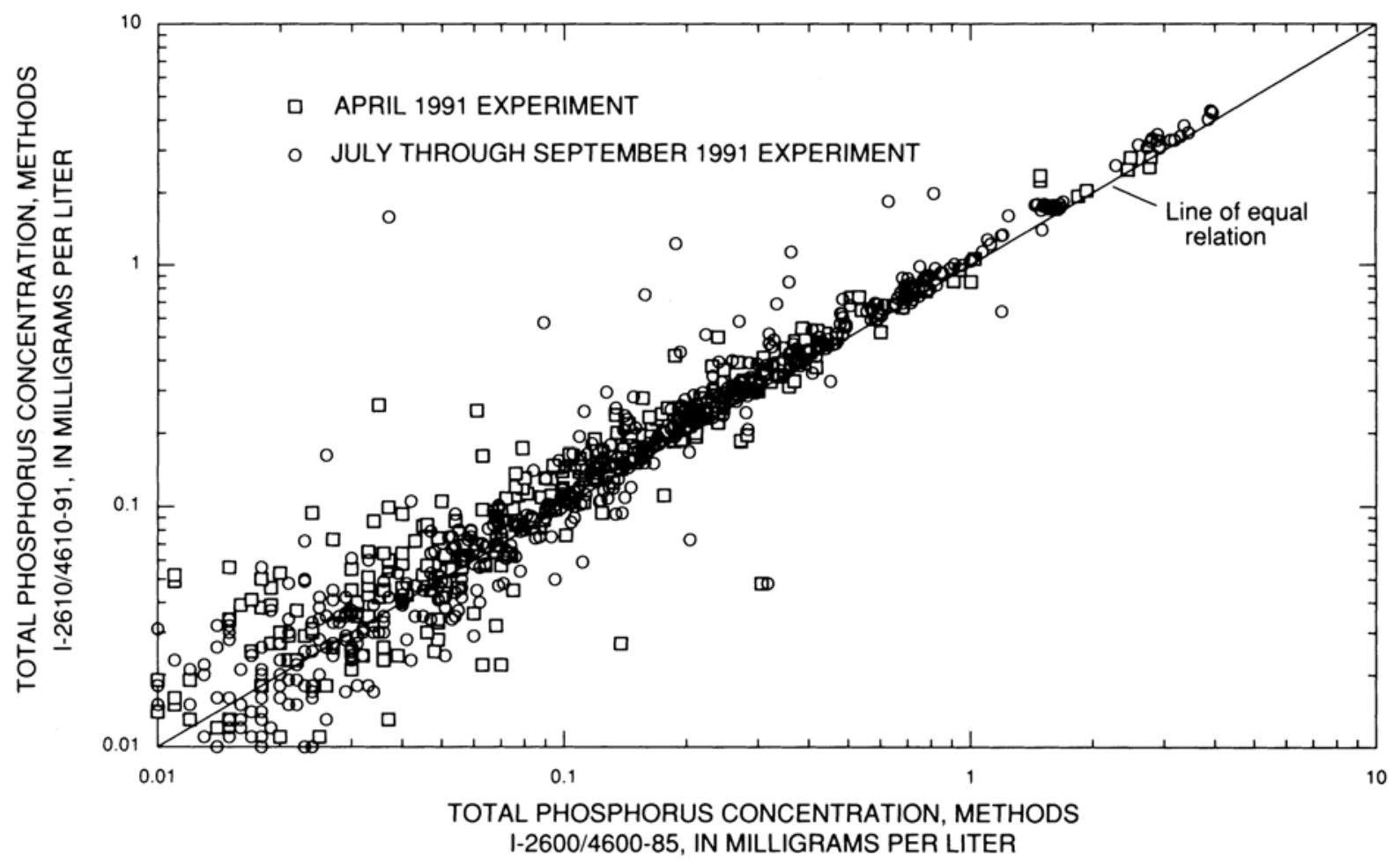

Figure 6. Relation between total phosphorus concentrations determined in unfiltered surface-water samples by methods I-2600/4600-85 and total phosphorus concentrations determined by methods I-2610/4610-91.

NOTE: Samples can be conveniently spiked prior to digestion as follows: Use an adjustable pipet $(100-1,000 \mu \mathrm{L})$ to dispense $1,000 \mu \mathrm{L}$ of primary inorganic or organic phosphorus calibrant into $\approx 20 \mathrm{~mL}$ of deionized water contained in a

$25-\mathrm{mL}$ volumetric flask. Dilute the resulting solution to the mark with deionized water and mix it well. When stored in a small amber bottle, this solution $(1.000 \mathrm{~mL}=0.02 \mathrm{mg} \mathrm{P})$ is stable for 6 months. To spike samples at a concentration of $0.2 \mathrm{mg} / \mathrm{L}$ of phosphorus, dispense $100 \mu \mathrm{L}$ of it directly into appropriate tubes prior to digestion. When TP and TKN are to be determined in the same digest, prepare a spiking solution that contains both phosphorus and nitrogen. 
Table 9. Paired $t$-test analysis of total phosphorus (TP) concentrations in filtered and unfiltered ground-water samples determined by methods I-2600/4600-85 (variable 1) and methods I-2610/4610-91 (variable 2) for the April 1991 experiment

[Negative values in the right-most column indicate the extent to which TP concentrations determined by methods I-2610/4610-91 exceeded those determined by methods I-2600/4600-85. See text for further details. mg/L, milligram per liter; p, probability level]

\begin{tabular}{cccccc}
\hline $\begin{array}{c}\text { Concentration } \\
\text { range } \\
(\mathbf{m g} / \mathbf{L})\end{array}$ & $\begin{array}{c}\text { Degrees of } \\
\text { freedom }\end{array}$ & $\begin{array}{c}\text { Two-sided } \\
\text { significance } \\
\text { level }\end{array}$ & $\begin{array}{c}\text { Reject null } \\
\text { hypothesis } \\
\text { at } \boldsymbol{p}=\mathbf{0 . 0 5}\end{array}$ & $\begin{array}{c}\text { t-Statistic } \\
\text { (calculated) }\end{array}$ & $\begin{array}{c}\text { Difference } \\
\text { between means } \\
\text { (mg/L) }\end{array}$ \\
\hline $0.00-0.70^{\mathrm{a}}$ & 31 & 0.0582 & No & -1.967093 & -0.01 \\
$0.00-0.21^{\mathrm{a}}$ & 29 & 0.1027 & No & -1.685195 & -0.01 \\
$0.00-3.25^{\mathrm{b}}$ & 19 & 0.4025 & No & 0.8563705 & 0.03 \\
$0.00-0.20^{\mathrm{b}}$ & 18 & 0.1002 & No & -1.733153 & -0.00 \\
\hline
\end{tabular}

aFiltered samples.

$\mathrm{b}_{\text {Unfiltered samples. }}$ 
Table 10. Paired $t$-test analysis of total phosphorus (TP) concentrations in filtered and unfiltered ground-water samples determined by methods I-2600/4600-85 (variable 1) and methods I-2610/4610-91 (variable 2) for the July through September 1991 experiments

[Negative values in the right-most column indicate the extent to which TP concentrations determined by methods I-2610/4610-91 exceeded those determined by methods I-2600/4600-85. See text for further details. $\mathrm{mg} / \mathrm{L}$, milligram per liter; $p$, probability level]

\begin{tabular}{cccccc}
\hline $\begin{array}{c}\text { Concentration } \\
\text { range } \\
(\mathbf{m g} / \mathbf{L})\end{array}$ & $\begin{array}{c}\text { Degrees of } \\
\text { freedom }\end{array}$ & $\begin{array}{c}\text { Two-sided } \\
\text { significance } \\
\text { level }\end{array}$ & $\begin{array}{c}\text { Reject null } \\
\text { hypothesis } \\
\text { at } \boldsymbol{p}=\mathbf{0 . 0 5}\end{array}$ & $\begin{array}{c}\text { t-Statistic } \\
\text { (calculated) }\end{array}$ & $\begin{array}{c}\text { Difference } \\
\text { between } \text { means } \\
\text { (mg/L) }\end{array}$ \\
\hline $0.00-0.34^{\mathrm{a}}$ & 15 & 0.8779 & No & -0.1563155 & -0.00 \\
$0.00-1.65^{\mathrm{b}}$ & 42 & 0.3831 & No & -0.8813688 & -0.01 \\
$0.00-0.23^{\mathrm{b}}$ & 40 & 0.3147 & No & 1.018189 & 0.00 \\
\hline
\end{tabular}

${ }^{a}$ Filtered samples.

bunfiltered samples. 


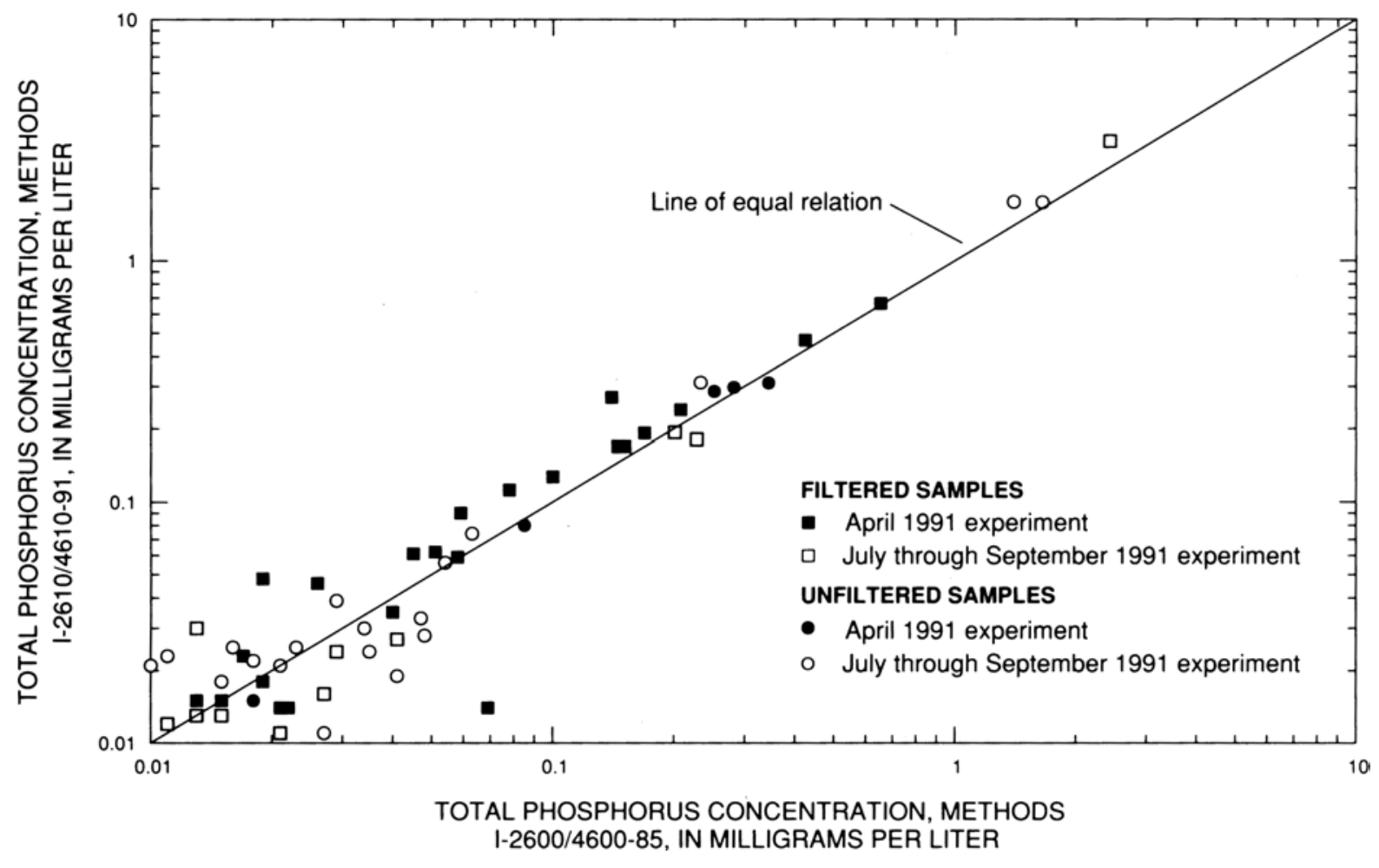

Figure 7. Relation between total phosphorus concentrations determined in filtered and unfiltered ground-water samples by methods I-2600/4600-85 and total phosphorus concentrations determined by methods I-2610/4610-91.

Because particulate laden, highly colored check standards generally are unavailable, tracking the imprecision component of accuracy with periodic duplicate determinations is advisable by maintaining an R-Bar Quality Control chart (Dux, 1986). Duplicate replication also can be monitored graphically by plotting concentrations determined for "trial 1 " in relation to those determined for "trial 2." Linear least-squares regression analysis of a data set in which duplicate replication was perfect would result in a y-intercept value of zero, and unity slope and correlation coefficient values. Another control chart approach, in which the difference between concentrations determined for "trial 1" and "trial 2" is plotted against the determination date, also can be useful. The concentration difference between spiked and unspiked samples can be plotted in a similar manner to monitor trends in spike recovery data. Examples of these types of QC plots for total phosphorus determined by methods I-2610/4610-91 during the month of April are shown in figures 11 through 13. 
Table 11. Total phosphorus concentrations determined by methods $\mathrm{I}-2610 / 4610-91$ for resolvated Heidelberg sample digests before and after passage through a 0.45 -micrometer nylon syringe filter

$[\mu \mathrm{m}$, micrometer; $\mathrm{mg} / \mathrm{L}$, milligram per liter $]$

\begin{tabular}{|c|c|c|}
\hline \multirow[t]{2}{*}{ Julian date } & \multicolumn{2}{|c|}{ Total phosphorus concentration (mg/L) } \\
\hline & Unfiltered & Filtered \\
\hline 98 & 1.57 & 1.59 \\
\hline 99 & 1.52 & 1.53 \\
\hline 99 & 1.50 & 1.49 \\
\hline 100 & 1.66 & 1.66 \\
\hline 100 & 1.57 & 1.56 \\
\hline 101 & 1.53 & 1.55 \\
\hline 101 & 1.54 & 1.55 \\
\hline 101 & 1.54 & 1.55 \\
\hline 101 & 1.56 & 1.55 \\
\hline 102 & 1.65 & 1.64 \\
\hline 106 & 1.58 & 1.58 \\
\hline 106 & 1.52 & 1.50 \\
\hline 106 & 1.60 & 1.59 \\
\hline 107 & 1.57 & 1.57 \\
\hline 107 & 1.58 & 1.59 \\
\hline 108 & 1.77 & 1.77 \\
\hline 108 & 1.57 & 1.56 \\
\hline 109 & 1.63 & 1.63 \\
\hline 109 & 1.67 & 1.69 \\
\hline 113 & 1.73 & 1.73 \\
\hline 113 & 1.52 & 1.50 \\
\hline 114 & 1.83 & 1.82 \\
\hline 114 & 1.60 & 1.58 \\
\hline 115 & 1.57 & 1.58 \\
\hline 116 & 1.68 & 1.70 \\
\hline 116 & 1.63 & 1.63 \\
\hline Average $(\mathrm{mg} / \mathrm{L})$ & 1.60 & 1.60 \\
\hline Standard deviation $(\mathrm{mg} / \mathrm{L})$ & 0.08 & 0.08 \\
\hline Number of points & $=26$ & 26 \\
\hline Relative standard deviation (percent) & $=\quad 5.00$ & $\mathbf{5 . 0 7}$ \\
\hline
\end{tabular}




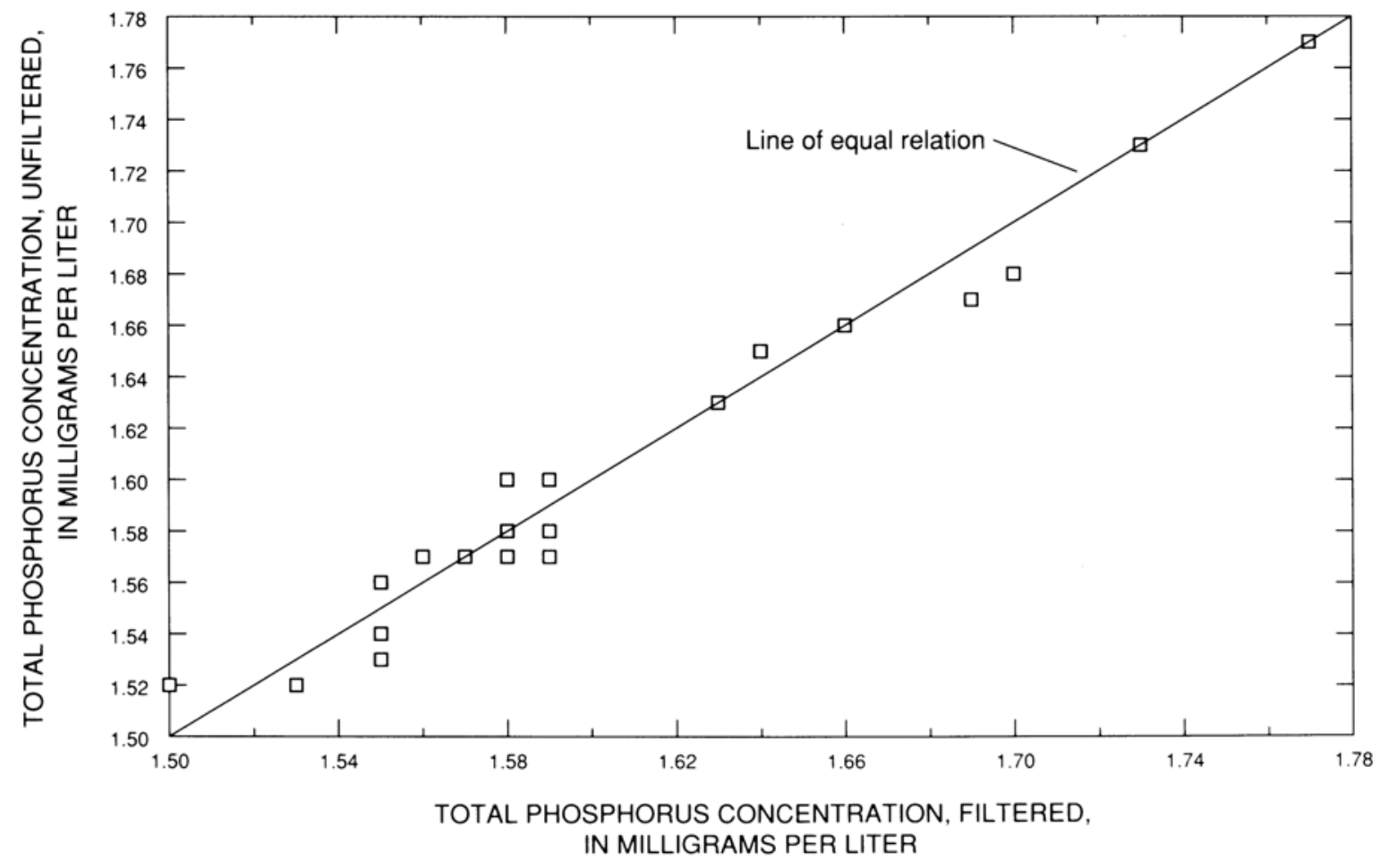

Figure 8. Relation between total phosphorus concentrations determined in filtered and unfiltered resolvated Heidelberg sample digests by methodsl-2610/4610-91. (Also see table 11.) 


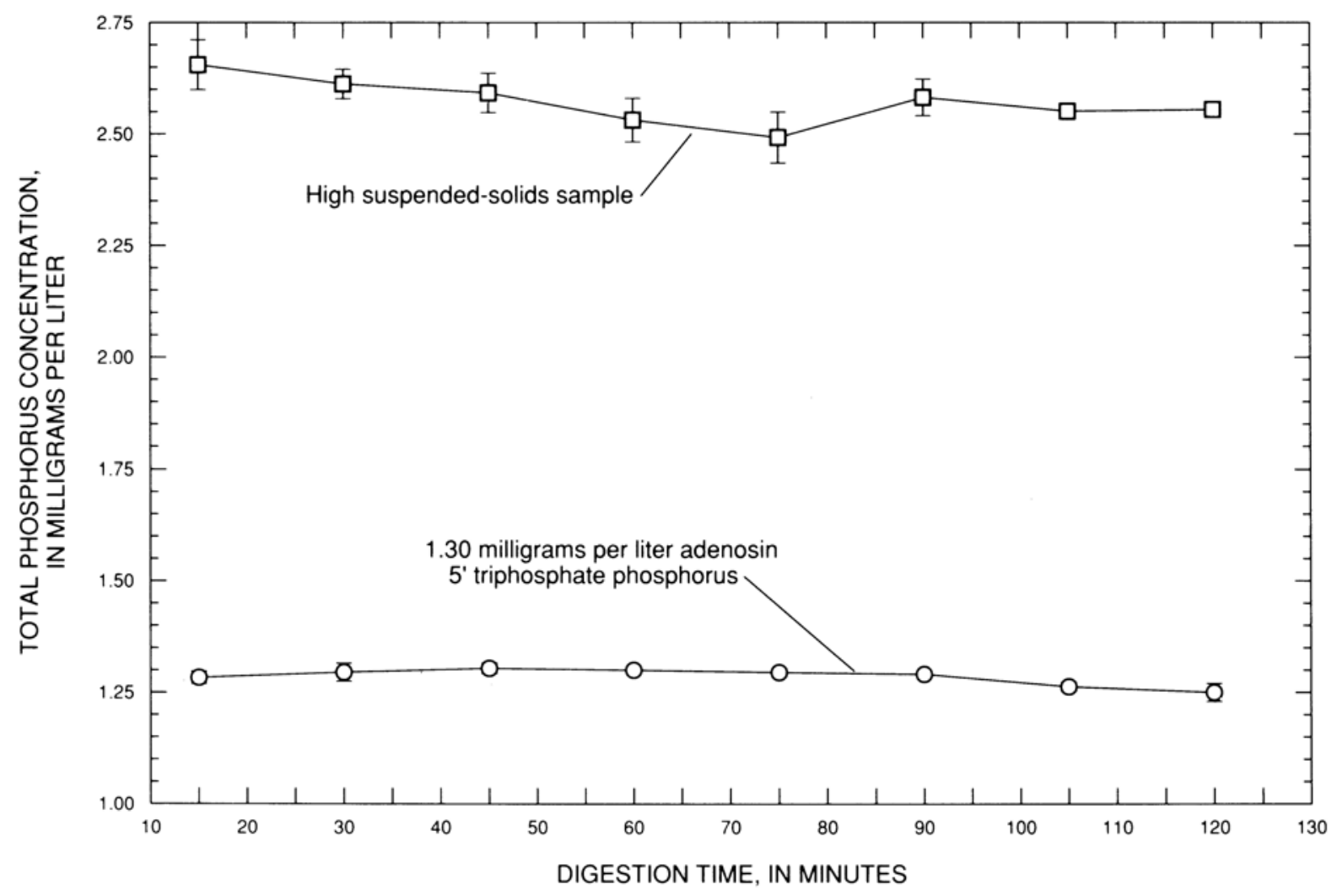

Figure 9. Total phosphorus concentration recovered for a sample in a high suspended-solids matrix and adenosin $5^{\prime}$ triphosphate in deionized water by methods I-2610/4610-91 as a function of hightemperature digestion time. Error bars represent \pm 1 standard deviation for the average of four determinations of each sample type at specified digestion times. 


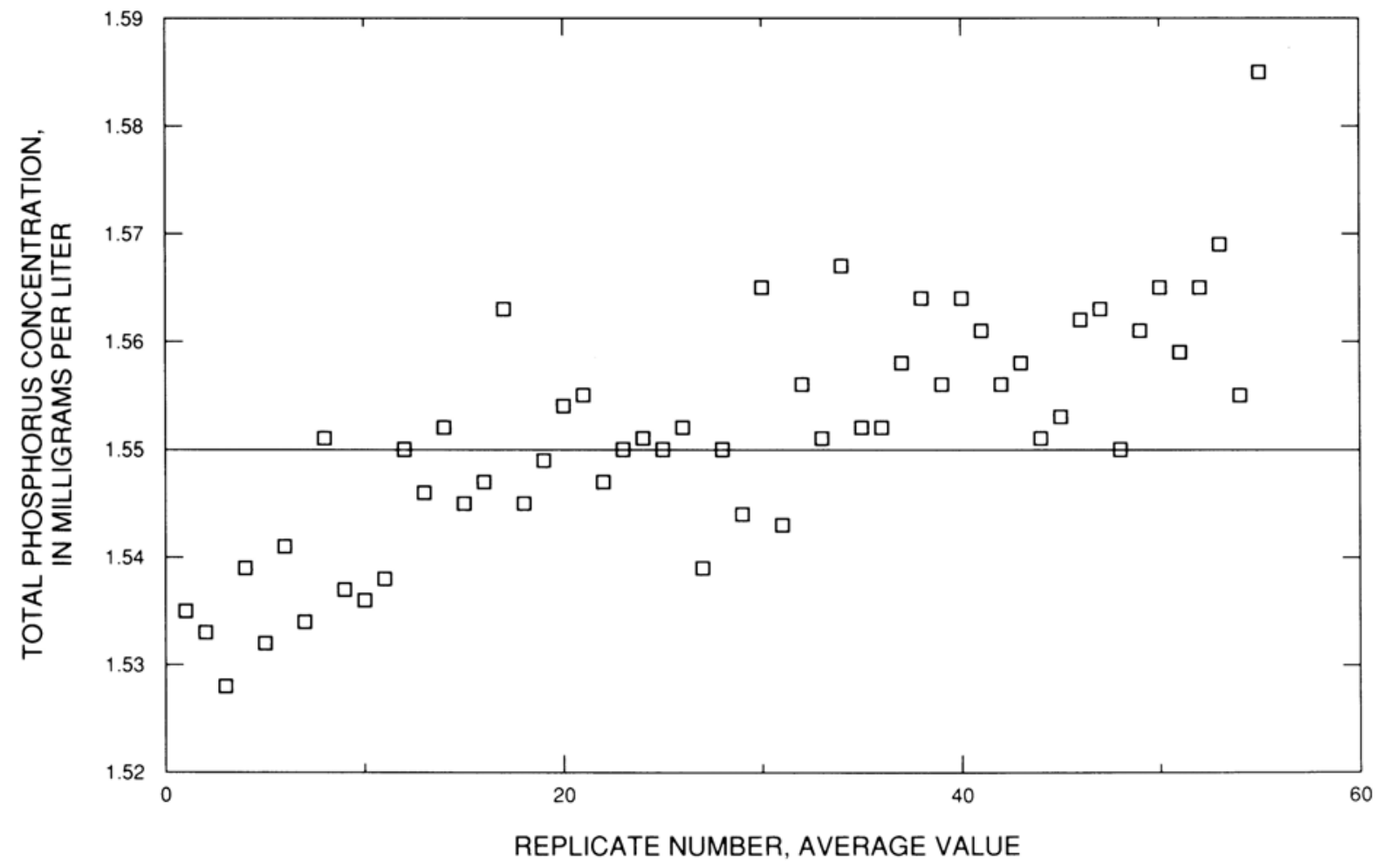

Figure 10. Repeatability (within-run precision) for 55 replicate determinations of the Heidelberg sample for total phosphorus concentration using methods I-2610/4610-91. 
Table 12. Repeatability (within-run precision, May 3, 1991) data for 55 replicate determinations of total phosphorus concentration in the Heidelberg sample using methods I-2610/4610-91

[mg/L, milligram per liter]

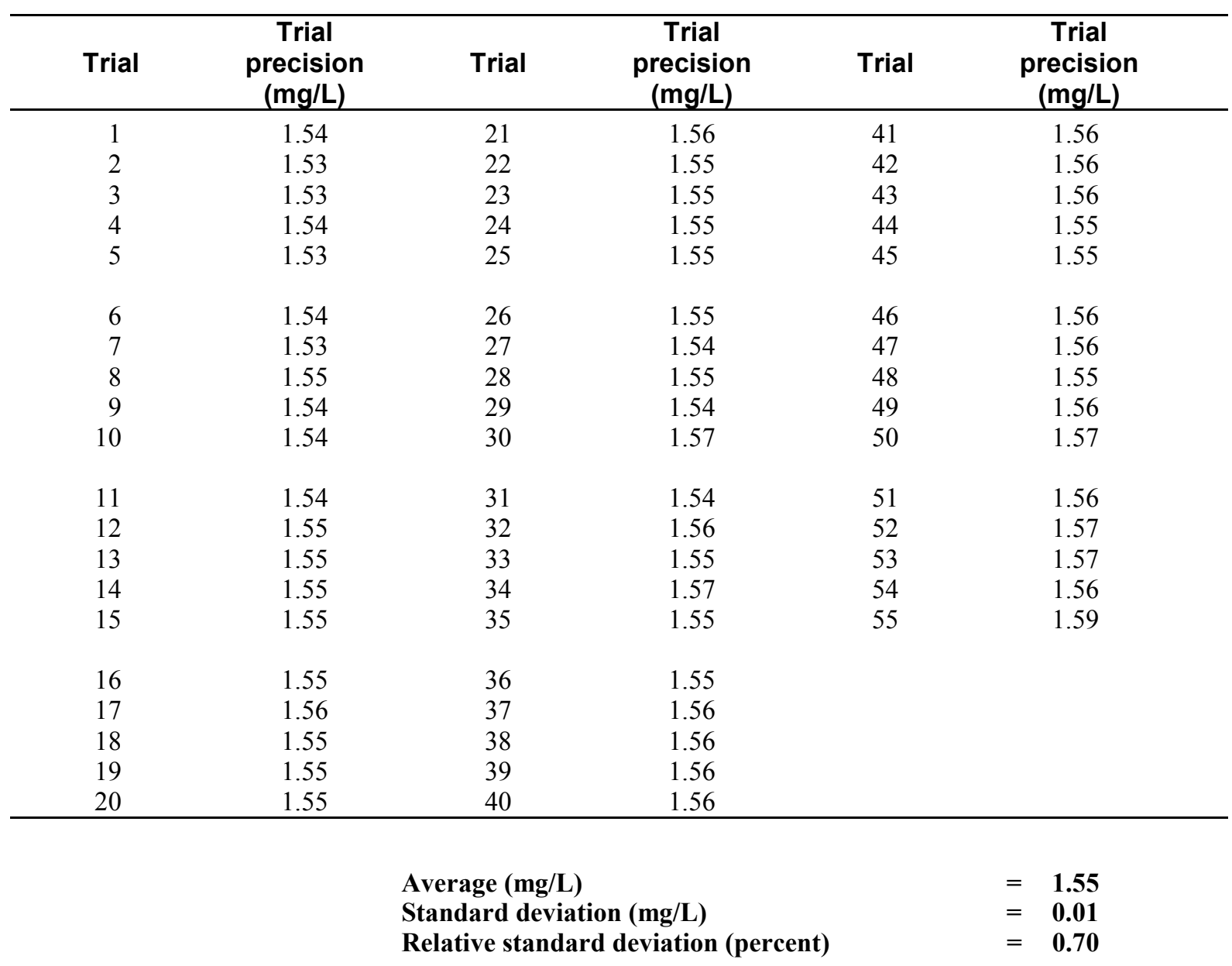


Table 13. Between-day (April 8-26, 1991) precision of digested calibrants and the Heidelberg sample for total phosphorus determination using methods I-2610/4610-91

$[\mathrm{mg} / \mathrm{L}$, milligram per liter; $\mathrm{n}$, number of points; $\overline{\mathrm{x}}$, average; std. dev., standard deviation; $\approx$, approximately; $\mu \mathrm{m}$, micrometer]

\begin{tabular}{|c|c|c|c|c|c|}
\hline $\begin{array}{c}\text { Sample } \\
\text { identification }\end{array}$ & $\begin{array}{c}\text { Nominal } \\
\text { concentration } \\
(\mathrm{mg} / \mathrm{L})\end{array}$ & $\mathbf{n}$ & $\bar{x}$ & $\begin{array}{l}\text { Standard } \\
\text { deviation }\end{array}$ & $\begin{array}{l}\text { Percent } \\
\text { relative } \\
\text { std. dev. }\end{array}$ \\
\hline CAL1 & 2.00 & 24 & 2.00 & 0.01 & 0.63 \\
\hline CAL2 & 1.50 & 25 & 1.50 & .02 & 1.05 \\
\hline CAL3 & 1.00 & 23 & 1.01 & .02 & 1.67 \\
\hline CAL4 & .50 & 25 & .50 & .02 & 3.62 \\
\hline CAL5 & .25 & 25 & .25 & .01 & 4.80 \\
\hline CAL6 & .10 & 25 & .09 & .01 & 6.73 \\
\hline HEIDELBERG ${ }^{1}$ & $3 \approx 1.6$ & 26 & 1.60 & .08 & 5.00 \\
\hline HEIDELBERG ${ }^{2}$ & $3 \approx 1.6$ & 26 & 1.60 & .08 & 5.07 \\
\hline
\end{tabular}

${ }^{1}$ Diluted digest was shaken and poured into analyzer cup.

${ }^{2}$ Diluted digest was dispensed into analyzer cup through a $0.45-\mu \mathrm{m}$ nylon syringe filter.

${ }^{3}$ National Water Quality Laboratory consensus value. 
Table 14. Between-day (April 8-26, 1991) accuracy of digested U.S. Environmental Protection Agency (USEPA) and U.S. Geological Survey reference samples for total phosphorus determination using methods I-2610/4610-91

$[\mathrm{mg} / \mathrm{L}$, milligram per liter; \pm , plus or minus; std. dev., standard deviation; $\mathrm{n}$, number of points; $\overline{\mathrm{X}}$, average; LCL, lower control limit; UCL, upper control limit; $\mu \mathrm{L}$, microliters; $\mathrm{mL}$, milliliters]

\begin{tabular}{|c|c|c|c|c|c|}
\hline $\begin{array}{c}\text { Sample } \\
\text { identification } \\
\end{array}$ & $\begin{array}{c}\text { Nominal } \\
\text { concentration } \\
(\mathrm{mg} / \mathrm{L})\end{array}$ & $n$ & $\bar{x}$ & $\begin{array}{l}\text { Standard } \\
\text { deviation }\end{array}$ & $\begin{array}{l}\text { Percent } \\
\text { relative } \\
\text { std. dev. }\end{array}$ \\
\hline $\begin{array}{l}\text { USEPA LOW }^{1} \\
(\mathrm{LCL}-\mathrm{UCL})^{2}\end{array}$ & $\begin{array}{c}0.76 \pm 0.06 \\
(0.64-0.89)\end{array}$ & 13 & 0.75 & 0.05 & 6.11 \\
\hline $\begin{array}{l}\text { USEPA Normal }^{3} \\
(\mathrm{LCL}-\mathrm{UCL})^{2}\end{array}$ & $\begin{array}{r}1.53 \pm 0.11 \\
(1.30-1.76)\end{array}$ & 10 & 1.54 & .09 & 5.92 \\
\hline $\begin{array}{l}\text { SRWS N-28 } \\
(\mathrm{LCL}-\mathrm{UCL})^{2}\end{array}$ & $\begin{array}{r}0.19 \pm 0.02 \\
(0.15-0.23)\end{array}$ & 16 & .17 & .05 & 27.04 \\
\hline $\begin{array}{l}\text { SRWS N-29 } \\
(\text { LCL - UCL) })^{2}\end{array}$ & $\begin{array}{r}0.57 \pm 0.04 \\
(0.49-0.64)\end{array}$ & 16 & .57 & .04 & 7.02 \\
\hline
\end{tabular}

\footnotetext{
${ }^{1}$ A $500-\mu$ L USEPA "Nutrient 2 " solution and $400-\mu \mathrm{L}$ National Water Quality Laboratory $\mathrm{HgCl}_{2} / \mathrm{NaCl}$ preservative solution diluted to $100 \mathrm{~mL}$ with deionized water.

${ }^{2}$ Confidence interval of 95 percent.

${ }^{3}$ A $1,000-\mu$ L USEPA "Nutrient 2" solution and 400- $\mu$ L National Water Quality Laboratory $\mathrm{HgCl}_{2} / \mathrm{NaCl}$ preservative solution diluted to $100 \mathrm{~mL}$ with deionized water.
} 


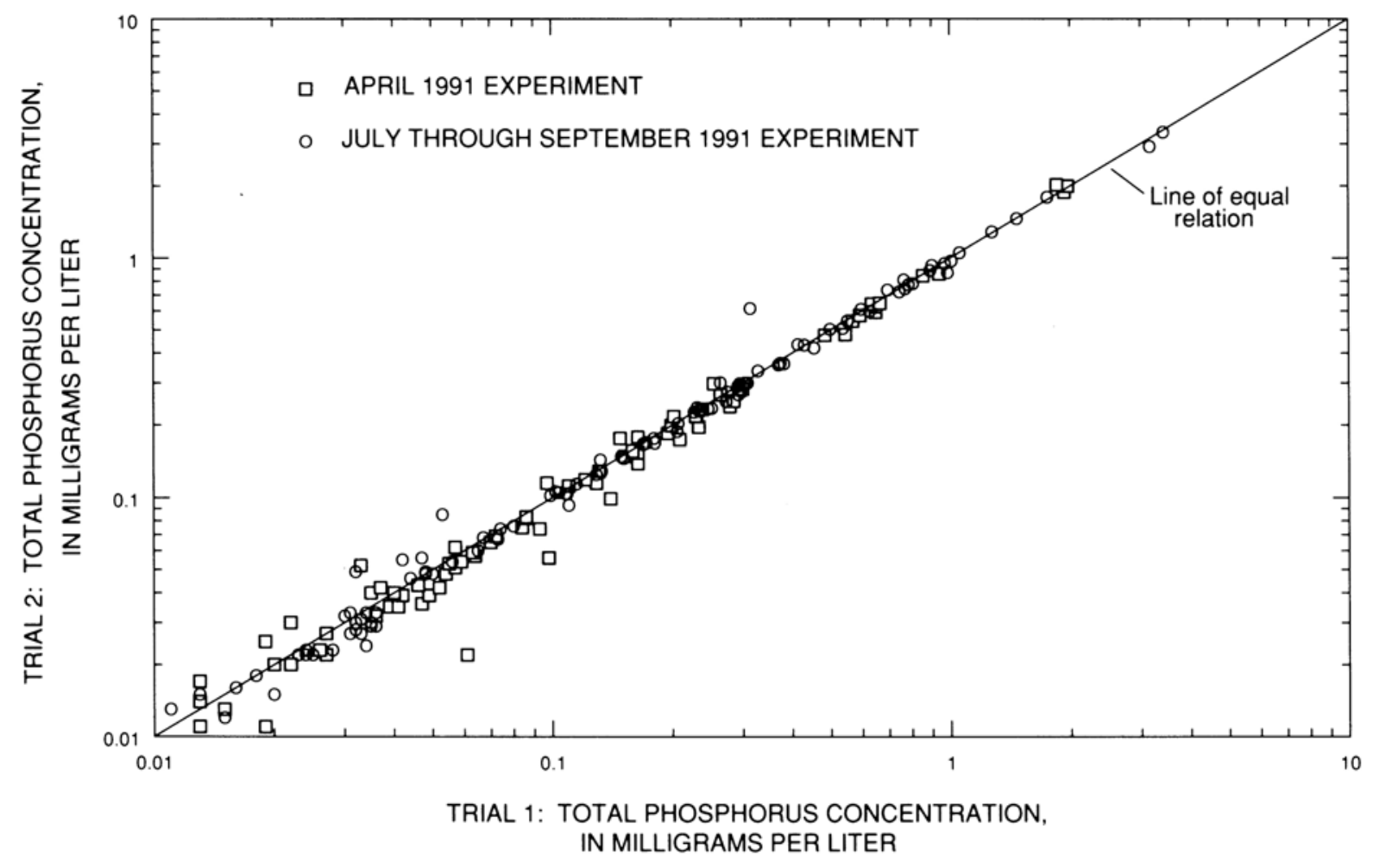

Figure 11. Duplicate replication for total phosphorus concentration determined by methods I-2610/4610-91. 


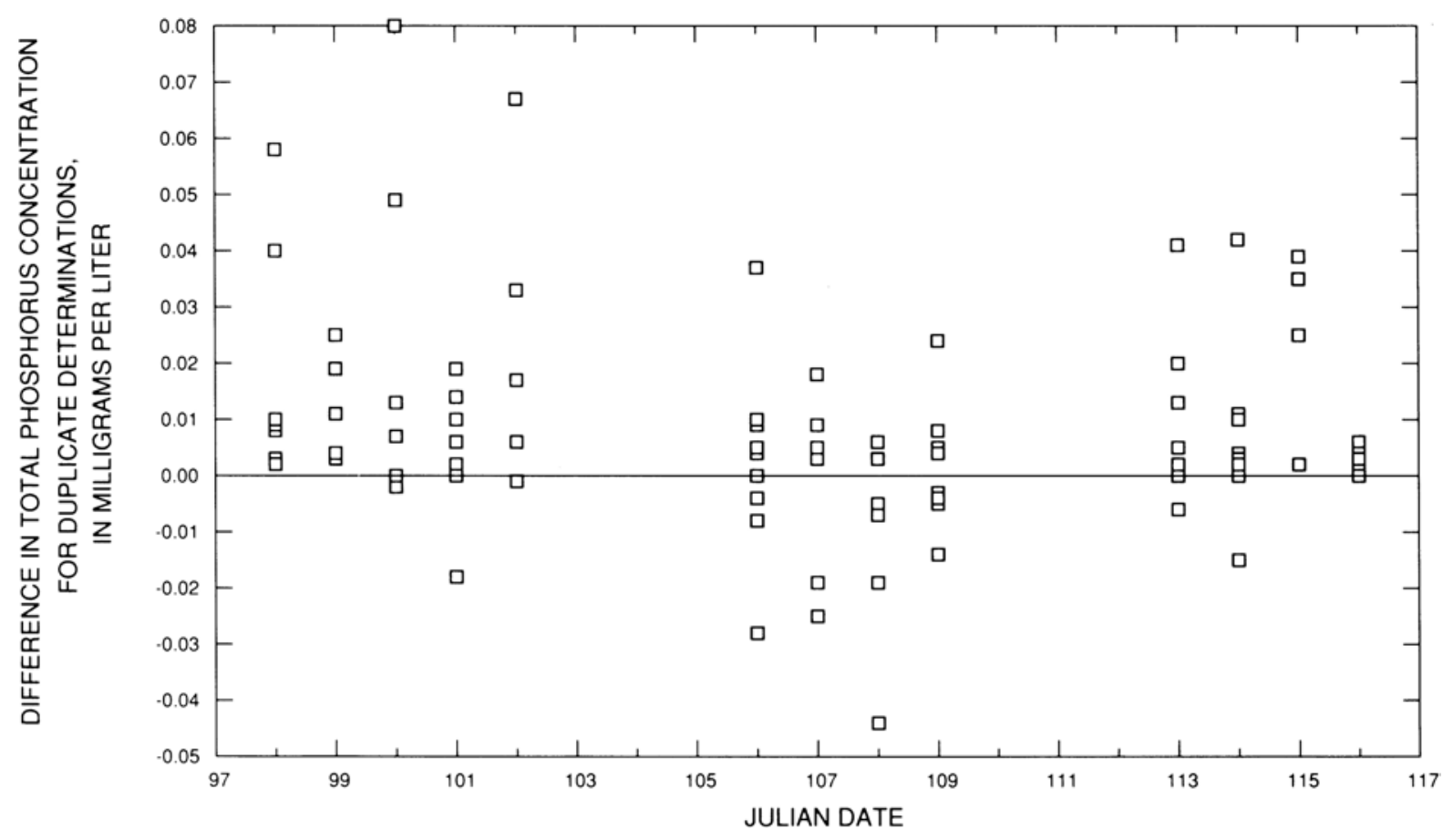

Figure 12. Duplicate replication during the April 1991 experiment for total phosphorus concentration determined by methods I-2610/4610-91. Number of points $=92$. 


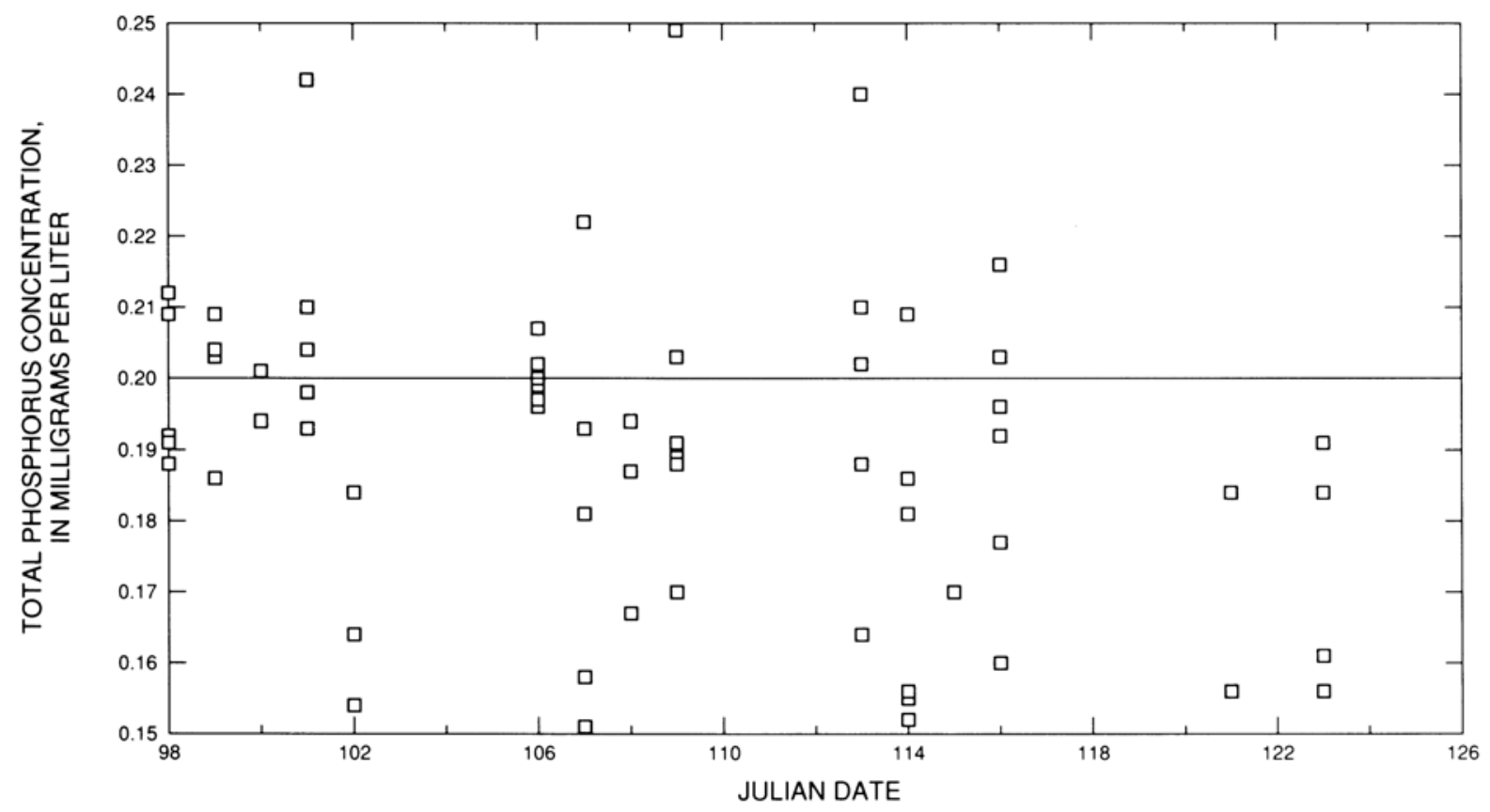

Figure 13. Spike recovery during the April 1991 experiment for total phosphorus concentration determined by methods I-2610/4610-91. Number of points $=73$, phosphorus added $=0.20$ milligram per liter, phosphorus found $=0.19 \pm 0.03$ milligram per liter, and average recovery $=95$ percent. 


\section{REFERENCES CITED}

Fishman, M.J., and Friedman, L.C., 1989, Methods for determination of inorganic substances in water and fluvial sediments: U.S. Geological Survey Techniques of WaterResources Investigations, book 5, chap. A1, 545 p.

Bowman, G.T., and Delfino, J.J., 1982, Determination of total Kjeldahl nitrogen and total phosphorus in surface waters and wastewaters: Journal of the Water Pollution Control Federation, v. 54, no., 9, p. 1324-1330.

Draper, N.R., and Smith, Harry, 1966, Applied regression analysis: New York, Wiley, 407 p.

Dux, J.P., 1986, Handbook of quality assurance for the analytical chemistry laboratory: New York, Van Nostrand Reinhold, p. 23-26.

Jirka, A.M., Carter, M.J., May, Dorothy, and Fuller, F.D., 1976, Ultramicro semiautomated method for simultaneous determination of total phosphorus and total Kjeldahl nitrogen in wastewaters: Environmental Science and Technology, v. 10, no. 10, p. 1038-1044.

Murphy, J., and Riley, J.P., 1962, A modified single solution method for the determination of phosphate in natural waters: Analytica Chimica Acta, v. 27, p. 31-36.

Pai, Su-Cheng, Yang, Chung-Cheng, and Riley, J.P., 1990, Effects of acidity and molybdate concentration on the kinetics of the formation of the phosphoantimonylmolybdenum blue complex: Analytica Chimica Acta, v. 229, p. 115-120.

Swartz, L.M., 1976, Nonlinear calibration curves: Analytical Chemistry, v. 48, no. 14, p. 2287-2290.

1977, Nonlinear calibration: Analytical Chemistry, v. 49, no. 13, p. 2062-2068.

1979, Calibration curves with nonuniform variance: Analytical Chemistry, v. 51, no. 6 , p. $723-727$.

U.S. Code of Federal Regulations, 1990, Definition and procedure for the determination of the method detection limit (7-1-90 ed.): Revision 1.11, pt. 136, App. B., p. 537-539.

U.S. Environmental Protection Agency, 1983, Methods for chemical analysis of water and wastes: Cincinnati, Ohio, Environmental Monitoring and Support Laboratory, USEPA600/4-79-020, p. 365.1-1 and 365.4-1.

U.S. Geological Survey, 1992, Programs and plans-Phosphorus methods and the quality of phosphorus data: Office of Water Quality Technical Memorandum No. 92.10, accessed April 28, 2003, at URL http://water.usgs.gov/admin/memo/QW/qw92.10.html

(Page modified: April 28, 2003) 